\title{
Modifications of structures and functions of caseins: a scientific and technological challenge
}

\author{
Camille Broyard · Frédéric Gaucheron
}

Received: 25 September 2014 / Revised: 13 February 2015 / Accepted: 23 February 2015 / Published online: 27 March 2015

(C) INRA and Springer-Verlag France 2015

\begin{abstract}
Casein molecules are used in food industry as ingredients. They can be used as isolated forms and under micellar form consisting in an association of different casein molecules and calcium phosphate. In this review, after a brief reminder of the main characteristics of casein molecules and casein micelles, the modifications of caseins induced by physical, chemical, and enzymatic actions are reported. The resulting new physicochemical properties (mineral and casein compositions, charge, hydrophobicity, aggregation state, and morphology) and techno-functionalities (heat stability, viscosity, gelation, emulsifying, and foaming properties) are described and discussed with a special attention paid to the results obtained in our laboratory since several decades.
\end{abstract}

Keywords Casein micelles · Physical, chemical, and enzymatic methods · Minerals · Stability $\cdot$ Functionality

\section{Introduction}

The four casein molecules ( $\alpha_{\mathrm{S}^{-}}, \alpha_{\mathrm{S}^{-}}, \beta$-, and $\mathrm{k}$-caseins) are well known in terms of amino acid composition, molecular weight, concentrations in milk, and global physicochemical properties (Table 1). All these casein molecules are more or less phosphorylated. This confers to these proteins a good capacity to bind calcium phosphate. Another important characteristic is the glycosylation of $50 \%$ of K-casein. Due to this glycosylation, its C-terminal part is hydrophilic. This characteristic is important for the micellar structure and stability. On the other hand, casein molecules have high contents in prolyl residues conferring open and flexible conformations. Due to their high flexibility, casein molecules have excellent surface-active and stabilizing properties.

\footnotetext{
C. Broyard · F. Gaucheron $(\bowtie)$

INRA, UMR1253 Science et Technologie du Lait et de l'Oeuf, F-35042 Rennes, France e-mail: Frederic.Gaucheron@rennes.inra.fr

C. Broyard · F. Gaucheron

Agrocampus Ouest, UMR1253 Science et Technologie du Lait et de l'Oeuf, F-35042 Rennes, France
}

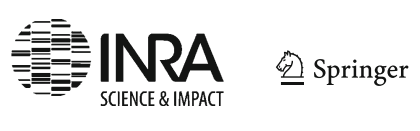


Table 1 General properties of casein molecules

\begin{tabular}{lllll}
\hline & $\begin{array}{l}\alpha_{\text {s1 }} \text {-casein } \\
(\mathrm{B} \text { variant })\end{array}$ & $\begin{array}{l}\alpha_{\text {s2 }} \text {-casein } \\
(\text { A variant })\end{array}$ & $\begin{array}{l}\beta \text {-casein } \\
\left(\mathrm{A}^{2} \text { variant }\right)\end{array}$ & $\begin{array}{l}\text { K-casein } \\
(\mathrm{B} \text { variant) }\end{array}$ \\
\hline Molecular weight (Da) & 23614 & 25230 & 23983 & 19023 \\
Concentration $\left(\mathrm{g} . \mathrm{L}^{-1}\right)$ & 10 & 2.6 & 9.3 & 3.3 \\
Amino acids & 199 & 207 & 209 & 169 \\
Proline & 17 & 10 & 35 & 20 \\
Cysteine & 0 & 2 & 0 & 2 \\
Glutamic acid & 24 & 25 & 18 & 13 \\
Aspartic acid & 8 & 11 & 5 & 1 \\
Phosphoserine & 8 & 11 & 5 & 1 \\
Apolar residues (\%) & 36 & 40 & 33 & 33 \\
Glycosylation & 0 & 0 & 0 & $0-5$ \\
Charge at pH 6.6 & -21 & -15 & -12 & -3 \\
\hline
\end{tabular}

The casein molecules are associated together to form casein micelles. Lot of researches focused on the understanding of the organization of casein micelles via different approaches and methods (from molecular to colloidal scale) and with special attention paid to protein-protein and protein-mineral interactions (Walstra 1990, 2002; Schmidt 1982; Horne 1986; Holt 1992; Holt and Horne 1996; Fox and McSweeney 1998; Swaisgood 1992, 2003; Tuinier and de Kruif 2002; De Kruif and Holt 2003; Dalgleish et al. 2004; Walstra et al. 2006; Qi 2007; Fox and Brodkorb 2008; Dalgleish 2011; Dalgleish and Corredig 2012; De Kruif et al. 2012; Holt et al. 2013). The casein micelles contain $\alpha \mathrm{s}_{1^{-}}, \alpha_{\mathrm{s}_{2}-}, \beta$-, and $\mathrm{K}$-caseins in proportions $40,10,35$, and $15 \%(w / w)$, respectively. Casein molecules are associated together by protein-protein interactions (hydrophobic, hydrogen, and electrostatic binding) and also by the presence of calcium and phosphate (6-8\% in weight). They have an average diameter close to $150 \mathrm{~nm}$ with a huge polydispersity, a zeta potential of about $-20 \mathrm{mV}$, and a high amount of associated water ( $4 \mathrm{~g}$ of water/g of protein). Other micellar physico-chemical characteristics are reported in Table 2. Different models of micellar organization were proposed thanks to the improvement of the methods used to their characterization. The main proposed models are (1) a submicellar model where the micelles correspond to submicelle assemblages linked together by nanoclusters of calcium phosphate (Morr 1967a, b; Schmidt 1982; Ono and Obata 1989; Walstra 1999), (2) a model with an open structure (Holt and Horne 1996), and (3) an open model like sponge (Marchin et al. 2007; Bouchoux et al. 2010; Dalgleish 2011). In this last proposed structure, dense regions composed of caseins in interaction with nanoclusters of calcium phosphate and water channels containing salts and caseins are described. In all of these models, the glycosylated forms of $\mathrm{k}$-casein are located at the surface of casein micelles, conferring them a negative charge and stability due to electrostatic repulsion and steric hindrance.

The aqueous phase of milk contains calcium, magnesium, sodium, and potassium as main cations and inorganic phosphate, citrate, and chloride as main anions. All these ions are associated together to form salts like calcium phosphate, calcium citrate, and sodium chloride. One part of them is also free under ionic form. Taking into account 
Table 2 Main physicochemical characteristics of casein micelles

\begin{tabular}{ll}
\hline Characteristic & Value \\
\hline Diameter & $150 \mathrm{~nm}$ (range $50-500 \mathrm{~nm}$ ) \\
Surface area & $8 \times 10^{-10} \mathrm{~cm}^{2}$ \\
Volume & $2.1 \times 10^{-15} \mathrm{~cm}^{3}$ \\
Density (hydrated) & $1.0632 \mathrm{~g} \cdot \mathrm{cm}^{-3}$ \\
Mass & $2.2 \times 10^{-15} \mathrm{~g}$ \\
Water content & $63 \%$ \\
Hydration & $3.7 \mathrm{~g} \mathrm{H} \mathrm{H}_{2} \mathrm{O} \cdot \mathrm{g}^{-1}$ \\
Voluminosity & $4.4 \mathrm{~cm}^{3} \cdot \mathrm{g}^{-1}$ \\
Molecular weight (hydrated) & $1.3 \times 10^{9} \mathrm{~g} \cdot \mathrm{mol}^{-1}$ \\
Molecular weight (dehydrated) & $5 \times 10^{8} \mathrm{~g} \cdot \mathrm{mol}^{-1}$ \\
Number of peptide chains & $5 \times 10^{3}$ \\
Number of particles per & $1014-10^{16}$ \\
$\quad$ milliliter of milk & $5 \times 10^{4} \mathrm{~cm}^{2}$ \\
Surface of micelles per & \\
$\quad$ milliliter of milk & $240 \mathrm{~nm}^{\text {Mean free distance }}$ \\
\hline
\end{tabular}

these different associations and free forms, the aqueous phase of milk at the native $\mathrm{pH}$ of 6.6-6.7 is supersaturated in calcium phosphate and has an ionic strength of about 70 mM (Holt 1997; Gaucheron 2004a, b; 2005). Casein micelles are in dynamic equilibrium with the aqueous phase. According to the physico-chemical conditions, they can exchange casein molecules, calcium, inorganic phosphate, and water with the aqueous phase (Fig. 1). In some cases, ions and casein molecules can be transferred from the micellar phase to the aqueous phase. In other cases, these constituents can be integrated in casein micelles.

The techno-functionalities of caseinates (sodium, potassium, or calcium) are largely used in the food industry. Caseinates can improve viscosity, structure, texture of gel, and emulsifying and foaming properties of different food products (Fox and Mulvihill 1983); Rollema 2003; Dickinson 2006). Conversely, the techno-functionalities of casein micelles are less studied and used in industry. However, understanding the relationship between their structures and functions is of major interest to propose new and innovative dairy products. The relationships between structures and technofunctionalities of purified casein molecules or casein micelles are complex but can be schematically represented as in Fig. 2 with intrinsic (casein) and extrinsic (environment) factors. All modifications of intrinsic or/and extrinsic factors can change the techno-functionalities of caseins. These modifications were either used to manufacture different dairy products or applied as strategy to understand the structurefunction relationships of the casein molecules or casein micelles.

Different processes or physico-chemical conditions can alter the structure and the techno-functionalities of proteins (Foegeding and Davis 2011; Chobert 2012). This is especially true for the casein molecules and casein micelles (Gaucheron 2004a, b; Augustin and Udabage 2007; Dalgleish and Corredig 2012). In this review, physicochemical, chemical, and enzymatic modifications are presented, as summarized in Table 3. The studies described in this review were performed with (1) purified casein 


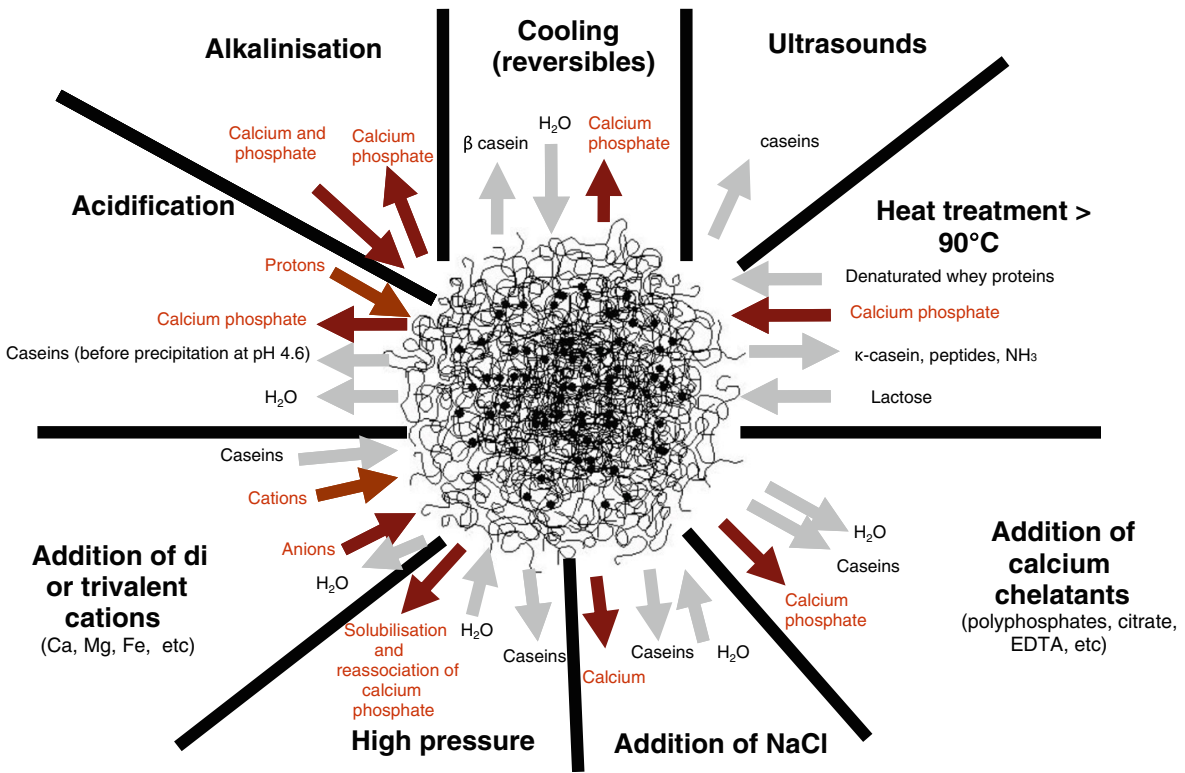

Fig. 1 Schematic exchanges of minerals, water, and casein molecules as a function of different physicochemical conditions (from Gaucheron 2004b)

molecules or (2) milk or (3) native casein micelles (also named native phosphocaseinate). The casein micelles are prepared from raw skim milk by microfiltration (pore size of $0.1 \mu \mathrm{m}$ ) combined with diafiltration with water to eliminate components of the soluble phase of milk (minerals, whey proteins, peptides, lactose...) (Pierre et al. 1992; Schuck et al. 1994). After their purification by membrane filtration, the micellar suspension is spray-dried. The advantage of this purification is to have the possibility to study the casein micelles alone in controlled conditions. It is indeed easier

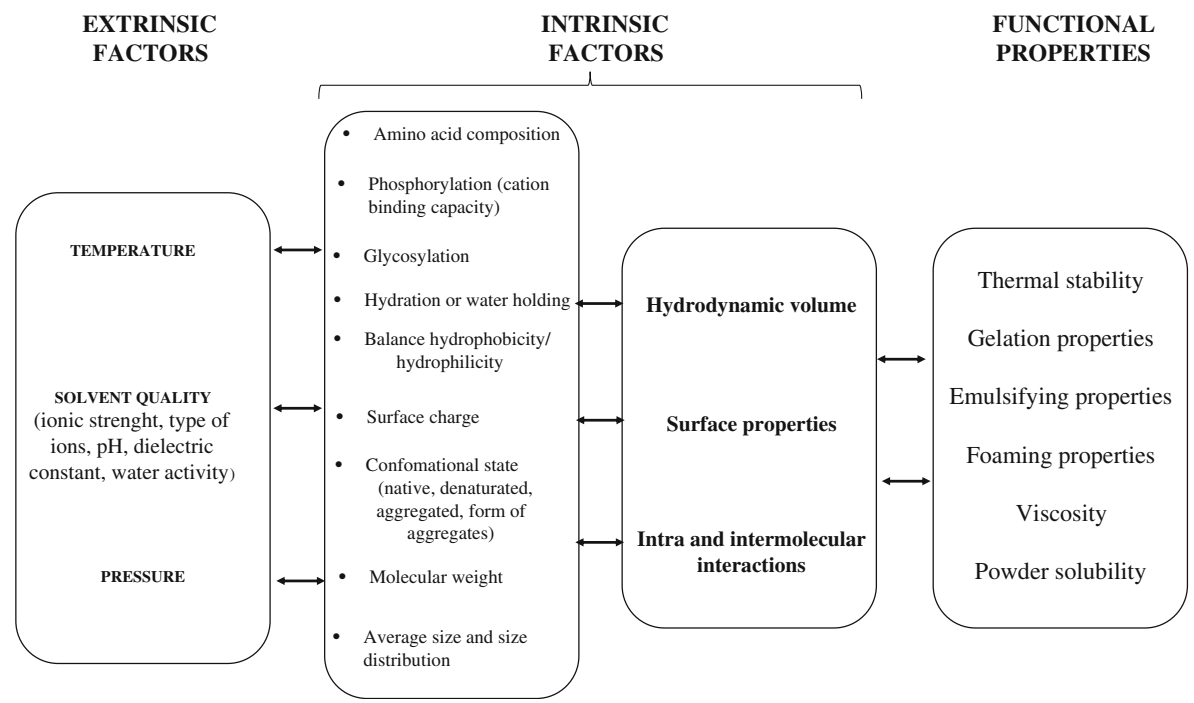

Fig. 2 Schematic relationships between structure and functionality of proteins 
to study suspended micellar casein in well-defined solutions. However, it is noteworthy that, after the use of membrane filtration, the casein micelles are not exactly in the same state as in the original milk. Alexander et al. (2011) and more recently Ferrer et al. (2014) reported that during ultrafiltration of milk combined with diafiltration with water, some changes in the physico-chemical properties of casein micelles were observed. Among the changes, they described progressive and irreversible removal of micellar calcium especially after diafiltration.

\section{Modification of casein molecules and casein micelles: actions and consequences on their structures and techno-functionalities}

\subsection{Physico-chemical modifications}

\subsubsection{Heating}

The casein molecules are remarkably heat-stable due to their lack of tertiary structure. However, different modifications depending on the intensity of the heat treatment have been highlighted. Some biochemical modifications are described such as desamidation of asparagine and glutamine residues, proteolysis (Gaucheron et al. 2001; Gaucheron 2001), and reticulation between amino acids, inducing protein polymerization, breakdown of disulfide bridges, and exchange of free thiols present on cysteine residues. The mineral fraction and especially calcium phosphate present in the aqueous phase is less soluble during heat treatment. The newly formed precipitate can interfere with casein micelles (Rose and Tessier 1959; Davies and White 1960) by modifying their surface. The composition, location, and interaction of this newly formed "micellar calcium phosphate" are not well defined in the literature. If the heat treatment is inferior to $95^{\circ} \mathrm{C}$ for a few minutes, the modifications of salt equilibria are reversible. In contrast, severe heat treatments (for example $120{ }^{\circ} \mathrm{C}$ during $20 \mathrm{~min}$ ) lead to irreversible changes for casein micelles and salt distribution. At temperatures higher than $110^{\circ} \mathrm{C}$, phosphoseryl residues of caseins can be partially hydrolyzed (Van Boekel 1999). For a heat treatment

Table 3 Methods to modify casein molecules or casein micelles

\begin{tabular}{lll}
\hline Physical methods & Chemical methods & Enzymatic methods \\
\hline $\begin{array}{l}\text { Heating or cooling } \\
\text { High pressure }\end{array}$ & $\begin{array}{l}\text { Glycation/lactosylation } \\
\text { Reticulation } \\
\text { Ultrasound }\end{array}$ & $\begin{array}{l}\text { Dephosphorylation } \\
\text { Deamidation }\end{array}$ \\
Decrease or increase of $\mathrm{pH}$ & Phosphorylation & Reticulation \\
Addition of di- and trivalent cations & & Deglycosylation \\
Addition of NaCl & & Proteolysis \\
Removal of diffusible ions & & \\
Addition of calcium chelatants & & \\
Addition of external ligands & & \\
\hline
\end{tabular}


higher than $70{ }^{\circ} \mathrm{C}$ for several minutes, covalent binding of whey proteins, mainly $\beta$ lactoglobulin, with caseins and aggregation are described (Oldfield et al. 2000; Donato and Guyomarc'h 2009). Increase in the hydrodynamic size of casein micelles and modification of their surface are reported as consequences (Anema and Li 2003; Tran Le et al. 2008). Lactose is also modified during heat treatment. It can be transformed in several compounds like organic acids, lactulose, and Maillard reaction products inducing browning of milk. Lactosylation of protein is also an important reaction induced by heat treatment. This reaction implies $\mathrm{NH}_{2}$ groups of basic amino acid residues like lysine and lactose (Van Boekel 1998). This reaction is relatively well described on whey proteins but not on casein micelles.

The technological consequences of heat treatment are multiple and described in different reviews, book chapters, and specific articles (Lucey et al. 2001; Vasbinder et al. 2003; Raikos 2010; Kethireddipalli et al. 2010; Dalgleish and Corredig 2012). The most well-known consequence of milk heat treatment is its loss of coagulability by rennet with an increase of the time of gelation and a decrease of gel firmness. By contrast, heating of milk improves firmness of acidic gels.

\subsubsection{Cooling at $4{ }^{\circ} \mathrm{C}$}

Cooling of milk is a common practice in dairy industry to microbiologically preserve milk before its transformation and consumption. The studies reporting the physico-chemical changes caused by cooling are few and old. Ichilczyk-Leone et al. (1981) showed an increase of about $1 \%$ of calcium and inorganic phosphate in the aqueous phase after cooling skim milk. Koutina et al. (2014) confirmed this trend and reported that at $4{ }^{\circ} \mathrm{C}$, the amounts of calcium and phosphorus in the soluble phase were more important than at $40{ }^{\circ} \mathrm{C}$. This is explained by a better solubility of calcium phosphate at low temperature. In the same time, a decreased amount of water associated to casein micelles and a release of $\beta$-casein from the micellar structure were described (Downey and Murphy 1970; Creamer et al. 1977; Pierre and Brulé 1981; Pouliot et al. 1994; Holt 1995). Indeed, temperature reduction modifies interactions between proteins, and consequently, this casein can be transferred into the aqueous phase. These changes are reversible and the previous partition may be reestablished after milk warming. Nevertheless, the native structure is not perfectly recovered because $\beta$-casein do not come back to their previous place. Liu et al. (2013) confirmed that the structure of casein micelle and the mineral system of milk were dependent on temperature in the range $10-40{ }^{\circ} \mathrm{C}$ by showing that the amount of soluble casein, hydration, and apparent voluminosity of casein micelles decreased as a function of increasing temperature. Moreover, the dynamic response of the mineral system to changes in temperature appears almost immediate when heating whereas re-equilibration of casein micelles is slower during cooling. Due to these modifications of interaction at low temperature, microfiltration of cold milk was proposed to purify $\beta$-casein at industrial level (Pouliot et al. 1994; Van Hekken and Holsinger 2000). Moreover, it might be interesting to use these new casein micelles (less mineralized, depleted in $\beta$-casein and more hydrated) to obtain new techno-functionalities. For example, Koutina et al. (2014) showed that the storage modulus $G^{\prime}$ at $\mathrm{pH} 4.8,4.7$, and 4.6 (gel formation) was higher for decreasing temperature $\left(4>20>30>40{ }^{\circ} \mathrm{C}\right)$. They concluded that the final texture of dairy products such as cheese could be modulated by the choice of the couple $\mathrm{pH}$ and temperature. 


\subsubsection{High pressure}

The structure of casein micelles is also modified by pressure treatments. Depending on the pressure level, the technology is called high-pressure homogenization or isostatic high pressure (up to 150-200 MPa) and ultra-high-pressure homogenization or dynamic high pressure (up to $350-400 \mathrm{MPa}$ ).

Concerning the effects of high-pressure treatment, several results obtained on milk with a special attention paid on milk proteins have been published for 25 years (Buccheim and Prokopeck 1992; Johnston et al. 1992; Shibauchi et al. 1992; Desobry-Banon et al. 1994; Gaucheron et al. 1997a; Schrader and Buchheim 1998; Huppertz et al. 2004a, b; Orlien et al. 2006; Huppertz and Kruif 2007; Bravo et al. 2013). The modifications of casein structure by high-pressure treatments are influenced by process parameters (pressure level, holding time, pressure release rate, temperature, and type of equipment) and by the composition of the dairy liquid $(\mathrm{pH}$, ionic strength, solvent composition, and protein concentration). The first visible impact of a high-pressure treatment (higher than $150 \mathrm{MPa}$ ) is a decrease of milk whiteness. The physico-chemical analyses of pressurized skim milk revealed a decrease in the hydrodynamic diameter of casein micelles, a decrease in turbidity, an increase in viscosity, an increase in casein micelle hydration, and slight solubilizations of micellar phosphorus and calcium. Partial solubilizations of $\alpha_{\mathrm{s} 1^{-}}$and $\alpha_{\mathrm{s} 2^{-}}$-caseins were also described (Regnault et al. 2006). These modifications are probably due to weakening of interactions between casein molecules themselves and also with colloidal calcium phosphate during the pressure treatment (Menéndez-Aguirre et al. 2014). After a return to atmospheric pressure, molecules of casein reassociate between themselves but not in the same organizational state as before the pressure treatment. The rate and the extent of casein disruption and reassociation were not affected by the presence of major whey proteins (i.e., $\beta$-lactoglobulin and $\alpha$ lactalbumin) (Huppertz and Kruif 2007). Results of Merel-Rausch et al. (2007) stated that, depending on the casein concentration (1 to $15 \%)$ and the pressure release rate, structures ranging from liquid (near Newtonian flow behavior) to a gel can be obtained.

The changes in the physico-chemical properties of casein micelles lead to modifications in their functionalities. Thus, acidification by glucono-deltalactone of pressurized milk induced a faster coagulation than for unpressurized milk (Desobry-Banon et al. 1994). High-pressure treatments (above $230 \mathrm{MPa}$ ) induced a decrease of the rennet clotting time (Shibauchi et al. 1992; DesobryBanon et al. 1994). The maximum buffering capacity was shifted from 4.8 to 5.0 for untreated milk to 5.2-5.4 for pressurized milks (Famelart et al. 1998). The gel strength increased with increasing high-pressure treatment (Johnston et al. 1992; Desobry-Banon et al. 1994) and a syneresis resistance was observed. Highpressure treatments appear as an interesting tool to entrap different ligands like curcumin, vitamin $\mathrm{D}_{2}$, and $\alpha$-tocopherol (Benzaria et al. 2013; Menéndez-Aguirre et al. 2011; Chevalier-Lucia et al. 2011). It increases the binding constant of these compounds to casein micelles. This could be related to the increased surface area of processed micelles since they were smaller and more numerous after highpressure treatment. 


\subsubsection{Ultrasound}

Ultrasonic processing could be an interesting technique for the food industry. This method consists in submitting samples to a sound wave of frequency between $16 \mathrm{kHz}$ and $10 \mathrm{MHz}$. The effects of this treatment on milk proteins are not well studied, and only few publications describe the effects of this physical treatment on casein. Madadlou et al. (2009) reported decreases in turbidity and diameter of particle suggesting disruption of casein micelles after their sonication (sonodissociation). The same authors (Madadlou et al. 2010) indicated a delay in the acid gelation time and an increase of the elasticity of gels formed with sonicated caseins. The gels contained a more interconnected structure and smaller non-distinguishable particles. These results were in accordance with those obtained by Vercet et al. (2002) and Riener et al. (2009) who reported that the rheological properties of yoghurt made with milk submitted to manothermosonication were improved in comparison with untreated milk. More recently, Liu et al. $(2014 b, c)$ indicated that ultrasonic treatment improved the properties of milk coagulation by rennet. The small reduction in the size of milk particles and changes in the protein hydrophobicity caused by physical effects from cavitation when applying low-frequency ultrasounds were the possible causes of this improvement of coagulation.

\subsection{5 $\mathrm{pH}$ decrease}

The structure and charge of casein molecules depend on the $\mathrm{pH}$ value. Decrease in $\mathrm{pH}$ reduces their ionization and induces changes on intra- and intermolecular interactions. Thus, during acidification of caseins, the phosphoseryl residues and carboxyl groups change their ionization state because they have an affinity for protons - their protonation depends on their $\mathrm{pKa}$ values. Thus, at neutral $\mathrm{pH}$, casein molecules are negatively charged. During acidification, they bind protons and casein molecules become less and less negatively charged to be neutral at their isoelectric $\mathrm{pH}$. At this $\mathrm{pH}$, casein molecules are aggregated and their solubilities are minimal.

The description of acidification of casein micelle is more complex than the one for casein molecules alone because micellar calcium phosphate is implied. Several hundred publications describe the different changes occurring during the decrease of $\mathrm{pH}$ (De Kruif 1997; McMahon et al. 2009). During milk acidification, the organic and inorganic phosphate, citrate, and carboxylic residues of caseins become more protonated (or less ionized). In the same time, the aqueous phase becomes less saturated in calcium phosphate due to a dissociation of this salt. Consequently, the micellar calcium phosphate is progressively dissolved with increases of calcium and inorganic phosphate concentrations in the aqueous phase (Visser et al. 1986; Dalgleish and Law 1988, 1989; Mekmene et al. 2010). This is accompanied by a dissociation of casein molecules which are transferred in the aqueous phase. The extent of mineral and casein dissociations depends on the $\mathrm{pH}$ value. At $\mathrm{pH} 5.2$, a part of calcium and the totality of the inorganic phosphate are solubilized. Calcium is totally solubilized at pH 3.5 (Le Graët and Brulé 1993; Mekmene et al. 2010). The pH-induced solubilizations of minerals from concentrated casein micelles are shifted toward lower $\mathrm{pH}$ values (Le Graët and Gaucheron 1999). In the same time, interactions between caseins themselves and between caseins and water are also affected because casein molecules are less and less 
charged. During acidification, the hairy layer of $\mathrm{K}$-casein shrinks and finally collapses. Consequently, the steric stabilization of casein micelles diminishes and, as a result, micelles exhibit attractive interactions (De Kruif 1997). In the $\mathrm{pH}$ range from 6.0 to 5.6, casein micelles swell and dissociation of caseins reaches a maximum at $\mathrm{pH} 5.6$ with a maximal dissociation of $\beta$-casein (Dalgleish and Law 1988). In this $\mathrm{pH}$ range, a new small population of caseins corresponding to casein aggregates is observed (Silva et al. 2013). These small particles have an average diameter of about 20-35 $\mathrm{nm}$ and a molecular weight between $10^{6}$ and $10^{7} \mathrm{~g} \cdot \mathrm{mol}^{-1}$. The proportion of this population smaller in size increases when the $\mathrm{pH}$ used to obtain the different casein suspensions is more acidic $(6.7<6.4<6.1<5.8<5.5)$. In terms of size, hydration, shape, and zeta potential, the non-dissociated casein micelles seemed similar to the native ones (Silva et al. 2013). The demineralization of casein micelles by decreasing the $\mathrm{pH}$ from 6.7 to 5.2 resulted in a reduced granular aspect of the micelles observed by cryo-transmission electron microscopy and atomic force microscopy (Marchin et al. 2007; Ouanezar et al. 2012) and the existence of a characteristic point of inflection in SAXS profiles (Marchin et al. 2007). At pH 4.6, the charge of caseins is equal to zero and consequently their solubility is minimal. Precipitation or gelation of caseins is observed.

The micellar destructuration induced by acidification is relatively similar with the different types of acid used (lactic, chlorhydric, citric). It is the $\mathrm{pH}$ value which mainly governs the physico-chemical changes. However, the composition of the aqueous phase especially its ionic environment as a function of acid types is not the same and this can influence the structure and functions of acidified caseins. Another remark concerns the $\mathrm{CO}_{2}$ use to reversibly acidify milk. With this treatment, Guillaume et al. (2004) reported some impacts on colloidal minerals, buffering capacity, and rennet coagulation which was improved.

The functional properties such as gel properties and heat stability of milk acidified at different $\mathrm{pH}$ values are strongly modified. Extensive information are described in different reviews and book chapters (Horne 1999). From a general point of view, at acid $\mathrm{pH}$, the heat stability is decreased whereas the rennet coagulation is improved with a decrease in the coagulation time (Van Hooydonk et al. 1986; Famelart et al. 1996; Liu et al. 2014a).

\subsection{6 $\mathrm{pH}$ increase}

Alkalinization is not commonly used in dairy industry and all the studies done at $\mathrm{pH}$ superior to 7 were performed to understand the salt equilibria, organization, and behavior of casein micelles in other $\mathrm{pH}$ conditions. After an increase of $\mathrm{pH}$ to 9, decreases in turbidity and whiteness of milk are described. Milk becomes transparent indicating a destruction of casein micelles with the presence of casein molecules in serum (Odagiri and Nickerson 1965a; Van Dijk 1991, 1992; Ahmad et al. 2009). In the same time, decreases in concentrations of calcium (especially ionic $\mathrm{Ca}$ ) and inorganic phosphate in the aqueous phase were observed. Ahmad et al. (2009) proposed that at alkaline $\mathrm{pH}$, the inorganic phosphate ion changes its ionization state from $\mathrm{HPO}_{4}{ }^{2-}$ to $\mathrm{PO}_{4}{ }^{3-}$. This last form of phosphate has a greater affinity for calcium, and consequently, a demineralization of casein micelles was induced. These decreases of mineral concentrations in the aqueous phase could improve the solvent quality and facilitate the dissociation of casein micelles by a diminution of cohesive interactions between the 
hydrophobic regions of caseins (Vaia et al. 2006). In addition to the mineral changes, these same authors and Huppertz et al. (2008) explained that the changes in the ionization of caseins could also contribute to this micellar disruption. To our knowledge, there are no published results on the techno-functionalities of alkalinized casein micelles.

\subsubsection{Addition of di- and trivalent cations}

Due to their negative charges at neutral $\mathrm{pH}$, the phosphoseryl residues and secondarily the carboxylic groups of acid residues have a strong affinity for di- and trivalent cations. A lot of results were published on the interactions between cations and molecules of casein, and it is admitted that these bindings depend on (1) the type of casein molecules $\left(\alpha_{\mathrm{s} 1}, \alpha_{\mathrm{s} 2}, \beta\right.$, or $\left.\mathrm{k}\right)$; (2) their phosphorylation state; (3) their charge; (4) the considered cations which can be different in terms of number of positive charge, size, and hydration; (5) type of binding (electrostatic or coordinative); and (6) the physico-chemical environment $(\mathrm{pH}$, ionic strength, temperature, presence of other compounds) (Gaucheron et al. 1997c; Gaucheron 2004a, b). The consequences of the binding of cations to casein molecules are a neutralization of their charge with an aggregation and precipitation of casein molecules if their binding sites are saturated by the added cations. The best example to show the influence of the cation type on the physico-chemical and techno-functionalities of casein molecules is the comparison between calcium caseinate and sodium caseinate. In terms of molecular organization and techno-functionalities, these two types of caseinate are different.

The description of the effects of addition of cations to milk or to casein micelles is more complex than those of addition of the same cations to molecules of caseins. Indeed, with milk, it is necessary to integrate that casein micelles are saturated in calcium phosphate (nanoclusters of calcium phosphate) and that they are in suspensions in aqueous phase also saturated in calcium and phosphate (Fig. 1). Theoretically, the mineral exchanges between aqueous and micellar phases are mainly controlled by the solubility of calcium phosphate of the aqueous phase. It is described that addition of divalent cations induces $\mathrm{pH}$ decrease and important modifications in the salt distribution between aqueous and micellar phases (Fig. 1) (Gaucheron 2004a, b). These modifications depend on (1) the nature of the aqueous phase, (2) the type of added cation (calcium, magnesium, iron, copper, zinc, etc.), (3) the added quantities, and (4) the eventual $\mathrm{pH}$ correction.

The calcium-induced modifications of salt balance in milk are the most described because this addition is largely practiced in dairy industry especially in cheese manufacture. Thus, after addition of $10 \mathrm{mM}$ of calcium chloride to milk, about $80 \%$ of this ion is associated to casein micelles. In the same time, inorganic phosphate and citrate ions are transferred from the aqueous phase to the micellar phase (Philippe et al. 2003, 2005; Mekmene et al. 2009). Consequently, the structure of casein micelles was modified with decreases in their zeta potential, hydration, and heat stability (Nieuwenhuijse et al. 1988). The buffering capacity was shifted towards lower $\mathrm{pH}$ in comparison with a non-enriched milk due to the formation of new micellar calcium phosphate (Salaun et al. 2007). Moreover, after addition of calcium to milk, its rennet coagulation was improved with a decrease in gelation time and an increase in gel firmness. On the contrary, addition of insoluble calcium salts like calcium phosphate 
does not change the physico-chemical and technological properties of enriched milks (Philippe et al. 2004; Omoarukhe et al. 2010).

Even if magnesium is a divalent cation like calcium, its addition to milk induces different effects in comparison with calcium. Modification of salt equilibria is less critical because magnesium-phosphate salt is not at saturation in the aqueous phase of milk. The low percentage of magnesium association with casein micelles can be explained by the low saturation indexes of salts like $\mathrm{MgHPO}_{4}$ and $\mathrm{Mg}_{3}\left(\mathrm{PO}_{4}\right)_{2}$ which are below 1. Due to these characteristics, the added magnesium interacts less than calcium with casein micelles and the consequences in terms of heat stability or rennet coagulation are less important than after calcium addition (Van Dijk 1991; Philippe et al. 2005).

Addition of iron, $\mathrm{Fe}^{2+}$ or $\mathrm{Fe}^{3+}$, to milk was also studied. Although the addition of iron is mainly performed for nutritional reason, the induced modifications of structure of the casein micelle could be used to improve techno-functionalities of milk enriched with iron. In suspensions containing only casein molecules, iron establishes coordinative links with oxygen atoms of phosphoseryl, aspartyl, and glutamyl residues (Gaucheron et al. 1996, 1997b; Raouche et al. 2009a, b). When iron is added to milk, it is mainly associated to casein micelles by interacting with organic and inorganic phosphates. The physico-chemical consequences of interactions between casein micelles and iron are decreases in zeta potentials and amount of water associated to casein micelles (Philippe et al. 2005). The technological consequences induced by the addition of iron depend on the state of oxidation of iron. The increases in times of clotting and aggregation and the decrease in the curd firmness are stronger with $\mathrm{Fe}^{2+}$ than with $\mathrm{Fe}^{3+}$ (Gaucheron et al. 1997b).

\subsubsection{Addition of $\mathrm{NaCl}$}

The structure, charge, and state of aggregation of casein molecules depend also on the $\mathrm{NaCl}$ concentration. Sodium ions act as counter ions of negative charge of phosphoseryl residues and carboxylic groups. At low ionic strength, casein molecules are individualized with electrostatic repulsions between themselves. In the presence of $\mathrm{NaCl}$, the electrostatic repulsions are screened and casein molecules associated together to form small aggregates. HadjSadok et al. (2008) reported changes of molecular weight and radius which increased from $2.5 \times 10^{4} \mathrm{~g} \cdot \mathrm{mol}^{-1}$ and $3 \mathrm{~nm}$ in the absence of added $\mathrm{NaCl}$ to $2.6 \times 10^{5} \mathrm{~g} \cdot \mathrm{mol}^{-1}$ and $11 \mathrm{~nm}$ in the presence of $100 \mathrm{mM} \mathrm{NaCl}$. The functionality of casein depends also on the $\mathrm{NaCl}$ concentration. Among the modifications, it is reported a best solubility of casein molecules close to the isoelectric point in the presence of $\mathrm{NaCl}$.

With casein micelles in milk conditions, the situation is more complex than with casein molecules. Milk contains sodium and chloride at the concentrations of 22 and $27 \mathrm{mM}$, respectively. Both ions are mainly present in the aqueous phase and partly contribute to the ionic strength evaluated to about $70 \mathrm{mM}$. When supplementary $\mathrm{NaCl}$ is added to milk or concentrated milks, $\mathrm{pH}$ slightly decreases and soluble calcium concentration increases (Le Graët and Brulé 1993; Huppertz and Fox 2006; Mekmene et al. 2009). These releases would correspond to exchanges between added sodium and calcium and protons bound directly to phosphoseryl residues of casein molecules. In the same time, the hydration of casein micelles is increased although their size and 
charge remain constant (Grufferty and Fox 1985; Van Dijk 1991; Casiraghi and Lucisano 1991; Le Ray et al. 1998; Famelart et al. 1999; Gaucheron et al. 2000; Huppertz and Fox 2006). High sodium concentration leads to a decrease in electrostatic repulsions between caseins, by shielding their negative charges. The casein-casein and casein-water interactions are modified. Karlsson et al. (2005) indicated that addition of $\mathrm{NaCl}$ to a milk concentrate induced the formation of rough micellar structure observed by transmission electron microscopy. The techno-functionalities of casein micelles are also different according to added $\mathrm{NaCl}$ concentration. Famelart et al. (1999) showed that the rennet gelation was delayed in the presence of $\mathrm{NaCl}$. An increase in viscosity was observed. Huppertz and Fox (2006) showed that addition of $\mathrm{NaCl}$ on concentrated milks induced a change in the heat coagulation time as a function of $\mathrm{pH}$ and a reduction of ethanol stability. Besides, addition of $\mathrm{NaCl}$ (up to $400 \mathrm{mM}$ ) shifted the maximum buffering capacity of milk from $\mathrm{pH} 5.2$ (without $\mathrm{NaCl}$ addition) to 5.5 (Salaun et al. 2007). The solubilization of micellar phosphate induced by addition of $\mathrm{NaCl}$ at high concentrations could be responsible for this shift of buffering capacity. Rehydration of micellar powder was improved in the presence of $\mathrm{NaCl}$ compared to a rehydration in water (Schuck et al. 1994; Hussain et al. 2011a, b; Schokker et al. 2011). To avoid a bad rehydration of micellar powder, Sikand et al. (2013) proposed to add $\mathrm{NaCl}$ or $\mathrm{KCl}$ during the diafiltration step. In these cases, the authors indicated that the added salts were probably responsible for structural modifications of casein micelles with as consequence an improvement of their rehydration.

\subsubsection{Removal of diffusible ions}

Membrane technologies are commonly used to concentrate milk proteins (ultrafiltration) or casein micelles (microfiltration with molecular weight cut-off of $0.1 \mu \mathrm{m}$ ). The use of these technologies allows to retain a protein fraction in the retentate and the small diffusible components (salts, free ions, lactose, peptides, amino acids, etc.) are able to pass through the membrane (filtrate). If a step of diafiltration with water (in general with 4-5 vol of the retentate volume) is performed before the final concentration, the diffusible components are removed (Pierre et al. 1992; Schuck et al. 1994). In this case, the ratio of mineral concentrations in colloidal and aqueous phases increases. It is also observed a $\mathrm{pH}$ increase due to the removal of buffering ions like inorganic phosphate. As the aqueous phase is water, the physico-chemical properties of caseins molecules are modified especially for their $\mathrm{pH}$ of precipitation (their apparent $\mathrm{pHi}$ increases when the ionic strength decreases). The consequences are also an increase of the electrostatic repulsions between caseins more negatively charged. Famelart et al. (1996) showed that casein micelles suspended in water formed a strong gel at acid $\mathrm{pH}$ and coagulated with a shorter renneting time than casein micelles suspended in presence in $\mathrm{NaCl}$ or in milk ultrafiltrate. Another example showing the importance of the aqueous phase is the difficulty to solubilize powder of purified casein micelle in water (Schuck et al. 1994).

\subsubsection{Addition of calcium chelatants}

Addition of calcium chelatants (citrate, EDTA, oxalate, pyrophosphate, polyphosphate, cation-exchange resins) to milk is studied since several years 
(Odagiri and Nickerson 1965b; Morr 1967a, b; Casiraghi and Lucisano 1991; Le Ray et al. 1998; Udabage et al. 2000; Pitkowski et al. 2008; Mekmene et al. 2009; Kaliappan and Lucey 2011), and there is no doubt about their demineralizing actions on the casein micelles. The chelatants act indirectly on casein micelles by chelating the ionic calcium $(2 \mathrm{mM})$ present in the aqueous phase. Consequently, the degree of calcium phosphate saturation of the aqueous phase is reduced and the solubilization of micellar calcium phosphate occurs. The extent of this micellar demineralization depends on the association constants (or calcium binding capacity) between calcium and chelatants. Due to this solubilization, the micellar suspensions or milk become less turbid and white (Mizuno and Lucey 2005). This decrease of turbidity corresponds to a destruction of the micellar structure with a release of small aggregates of non-sedimentable casein molecules in the aqueous phase. Pitkowski et al. (2008) showed that these small aggregates contained 10-15 casein molecules with hydrodynamic radius of about $10 \mathrm{~nm}$. The zeta potential of casein becomes more negative because interactions between phosphoseryl residues and calcium are reduced.

These additions of chelatants by modifying the organization of casein micelles can prevent some important problems like deposit formation on heat exchangers and membrane surfaces. They are also interesting in the development of innovative products because the addition of chelatants improves heat stability and storage life of milk products especially concentrated milk. These salts are also used in the manufacture of processed cheese. As a consequence of their chelating actions, these molecules quantitatively and qualitatively modify the buffering capacity of dairy liquids. Quantitatively, the buffering capacity increases because the chelating molecules have acido-basic groups which are able to bind protons and resist to the decrease in $\mathrm{pH}$. The maximal buffering capacity is also shifted toward lower or higher $\mathrm{pH}$ (in comparison with micellar suspension without chelatant) depending on $\mathrm{p} K$ values of chelatants (Salaun et al. 2007).

In relation with these physico-chemical modifications, the calcium chelatants alter the technological properties of casein. De Kort et al. (2011) indicated that the presence of chelatant induced an increase in viscosity due to the presence of these small aggregates. The apparent shear modulus and the resistance to syneresis increased in acid gels containing calcium-chelating agents (Johnston and Murphy 1992). This was confirmed by Ozcan-Yilsay et al. (2006) who indicated that the addition of trisodium citrate (between 10 and $15 \mathrm{mM}$ ) to milk improved the textural properties of acid gel and reduced the whey separation. Improvement in foaming properties was also described after addition of hexametaphosphate (Kelly and Burgess 1978), EDTA (Ward et al. 1997), or citrate (Augustin and Clarke 2008) to milk. Schuck et al. (2002) and Schokker et al. (2011) indicated that solubilization of micellar powder was improved in presence of citrate (in comparison with solubilization in water). Ye (2011) indicated that stable emulsions were formed in presence of protein concentrates having low micellar calcium content. This improvement was in relation with the mineralization and organization of casein. With a high micellar calcium content, casein are under micellar form $(200 \mathrm{~nm})$ and on the contrary, with a low micellar calcium content, caseins form small aggregates $(30-50 \mathrm{~nm})$ which are able to stabilize emulsion by their presence at the oil-water interface. 


\subsubsection{Addition of external ligands}

Some publications report the effect of addition of external molecules on the structure and functionality of caseins used as vector (in most cases, the added molecules were interesting for health). In general, there are interactions between casein molecules and the added compounds. Sometimes these new interactions affect the structure of caseins and also their functional properties. In this context, O'Connell and Fox, in a review published in 2001, reported significance and applications of phenolic compounds on the quality of milk and dairy products. They indicated that these compounds interact with casein by hydrophobic and hydrogen bindings or after chemical reactions. One of the consequences of the interactions between caffeic and ferulic acids and casein micelles was an increase of their heat stability. Kartsova and Alekseeva (2008) reported that tea catechins were also able to be bound to casein micelles. This is interesting for application of coffee/tea whiteners. The binding sites were not clearly identified, but it was suggested that proline residues were involved in these interactions. Recently, Haratifar and Corredig (2014) indicated that this association increased the time of milk gelation after rennet addition. For the authors, this effect was in relation with a modification of the enzymatic cleavage leading to a slower release of caseinomacropeptide after rennet addition. For the authors, the accessibility of the enzyme to K-casein was probably limited. Harbourne et al. (2011) reported that addition of tannic and gallic acids modified the formation of acid gel. In the presence of phenolic compounds, the gelation time was faster. These additions induced also a higher storage modulus and a decrease in the water mobility, and no effect on the syneresis was determined. Titapiccolo et al. (2010) showed that (1) the rennet gelation of casein micelles was accelerated in the presence of different nonionic surfactants and (2) higher elastic modulus were obtained in their presence. By varying the size of the surfactant (Tween 20 or Tween 80 ) as well as the colloidal state of casein, these authors showed that the surfactant had a direct effect on the casein micelles.

\subsection{Chemical modifications}

\subsubsection{Reaction with sugars}

It is an interesting method to improve the functional properties of food proteins (Liu et al. 2012) and especially casein. This can be done through a chemical combination of a free aldehyde function of sugar with $\varepsilon$-amino groups of lysyl residues. Sugar can be lactose (reaction of lactosylation) but also glucose, sucrose, mannose, and other (reaction of glycation). All casein molecules are concerned by these reactions because all contain lysyl residues (Swaisgood 1992). These reactions occur naturally or are induced especially during heat treatment or storage (Siciliano et al. 2000; Le et al. 2013). Glycation can be followed by evaluation of the number of the free amino groups of lysyl residues and more precisely by mass spectrometry (Steffan et al. 2006; Siciliano et al. 2013). Courthaudon et al. (1989) reported that glycation of casein with glucose, fructose, galactose, mannose, maltose, or lactose improved their solubility especially close to their isoelectric point (but it remained unchanged at neutral and alkaline $\mathrm{pH}$ and decreased at low $\mathrm{pH}$ values). Increases of viscosity were also described by these authors. Colas et al. (1988) showed that 
glycation of casein with galactose, glucose, fructose, lactose, and maltose resulted in an increase of voluminosity of casein. Closs et al. (1990) described an improvement of the foaming properties (capacity and stability) when caseins were glycated. They explained this change by an increase in the flexibility of glycated casein allowing a more rapid absorption at the water-air interface (in comparison to nonglycated caseins). Darewicz et al. (1999a) studied the impact of glycation and enzymatic dephosphorylation on $\beta$-casein. In this study, ten glucose and nine lactose were bound to casein while all phosphate groups were removed. After these modifications, they concluded that glycation (1) shifted the pHi of casein toward more acidic $\mathrm{pH}$ values and (2) decreased the solubility at acid $\mathrm{pH}$. In another publication, the same team (Darewicz et al. 1999b) reported structural changes deduced by modification of absorption spectra in UV and a better heat stability of $\beta$ casein after its glycation. Corzo-Martinez et al. (2010) worked on the characterization and improvement of rheological properties of glycated sodium caseinate with galactose, lactose, and dextran. They showed a higher reactivity to form glycoconjugates for galactose compared to lactose and dextrans, due to its smaller molecular weight. Reaction with galactose and lactose increased the viscosity of caseinate. In addition, the flow characteristics of glycated caseinates were modified, passing from a Newtonian behavior to a shear-thinning behavior. On the contrary, glycation with dextran did not improve the rheological properties of caseinate, probably due to the limited extent of the reaction. Similarly, Oliver et al. (2006) reported that glycated sodium caseinate with ribose, glucose, fructose, lactose, and inulin have increased viscosities compared to unmodified sodium caseinate with a non-Newtonian behavior. According to these authors, the main cause of increased viscosities was related to an increase of bound water to the glycated proteins. Preparations of glycated caseinate with maltodextrin were described by O'Regan and Mulvihill (2009). The reactions were performed at $60{ }^{\circ} \mathrm{C}$ and $79 \%$ of relative humidity for 4 days. The conjugates have an improved solubility compared to unmodified caseinate, particularly around their isoelectric point. Moreover, oil/ water emulsions were more stabilized with the glycated caseinate compared to unmodified caseinate.

It is also possible to induce reaction between caseins and lactose (reaction of lactosylation). In a general way, the extent of lactosylation depends on several factors such as (1) intensity of heat treatments, (2) type and structure of the considered protein (van Boekel 1998; Scaloni et al. 2002), (3) lactose/protein ratio (Evangelisti et al. 1994), and (4) environmental conditions like $\mathrm{pH}$. The literature describing the reaction of lactosylation and its effects on casein micelles is relatively poor. In contrast, reaction between lactose and purified casein molecules (and also whey proteins) is better described, especially with $\alpha_{\mathrm{S} 1^{-}}$and $\beta$-caseins because they contain important amounts of lysyl residues (Swaisgood 1992). The consequences of the lactosylation of casein molecules are multiple and complex. It is reported a modification of enzymatic proteolysis of lactosylated proteins. Thus, Dalsgaard et al. (2007) showed that lactosylation of $\alpha$-, $\beta$-, and $\kappa$-caseins, $\beta$-lactoglobulin, or lactoferrin affected negatively their hydrolysis by plasmin, especially for the globular proteins. In the same way, Bhatt et al. (2014) indicated that a high level of lactosylation of lysyl residues present on $\beta$-casein affected the plasmin-induced hydrolysis. In contrast, lactosylation of caseins did not affect significantly their cleavage by cathepsin D and chymosin.

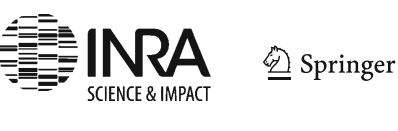




\subsubsection{Chemical reticulation}

An alternative to modify casein structure is its chemical reticulation. One of the most known chemical agents is glutaraldehyde. Silva et al. (2004) showed that this bifunctional compound was able to link lysyl residues to form aggregates with high molecular weight. However, no intensive research was made with this chemical agent due to its toxicity. Another reagent is the genipin, a natural molecule extracted from the fruits of Gardenia jasminoides (Endo and Taguchi 1973; Song et al. 2009). As its toxicity seems limited, this molecule was investigated as a cross-linking agent in many biological applications (Chaubaroux et al. 2012). In recent works, Silva et al. (2014) and Nogueira Silva et al. (2015) have characterized the casein micelles cross-linked by genipin. After reaction, micellar suspension was blue in color. These authors showed that reticulated casein micelles were (1) formed via cross-linking with lysyl and arginyl residues, (2) smaller in size, and (3) more negatively charged and have a smoother surface than native casein micelles. Light scattering measurements showed that the reaction between genipin and casein molecules was mainly intra-micellar with the determination of only one population of particles. The viscosity of the modified micellar suspensions was reduced. These reticulated casein micelles were not dissociated in presence of citrate and urea or at the air-solution interface where they formed rather a solid than a viscoelastic gel. In terms of techno-functionality of these type of reticulated casein micelles, no results are reported in the literature. It is probable that some similarities with casein micelles reticulated by transglutaminase would be determined ("Reticulation" section). Another chemical compound is also described named cinnamaldehyde able to cross-link proteins like chitosan (Nipun Babu and Kannan 2012). To our knowledge, no result is reported on milk protein but such compound could be interesting to reticulate casein molecules or casein micelles.

\subsubsection{Succinylation/acylation}

The reactions of succinylation and acylation concern the free amino groups of lysyl residues of casein molecules with as consequence modifications of their physicochemical properties, especially their charge.

Succinylation The reaction of succinylation is performed by addition of succinic anhydride to caseins. The result of this reaction is a covalent attachment of succinate groups containing one negative charge per group. One of the consequences of this reaction is an increase of the net negative charge of the caseins inducing a shift of $\mathrm{pHi}$ of caseins toward a lower $\mathrm{pH}$ value. In addition, increases of electrostatic repulsions due to the increase of the negative charges of caseins were induced (Vidal et al. 2002). Hoagland (1966) indicated that succinylated $\beta$-casein remained soluble in the presence of $25 \mathrm{mM}$ added calcium whereas unmodified $\beta$-casein was totally precipitated. According to Lieske (1999), there is also a calcium depletion for the succinylated casein micelles, a decrease in their surface hydrophobicity, and an increase of their diameter. Lakkis and Villota (1992) reported spectral changes of fluorescence and circular dichroism of caseins after their succinylation.

As consequence of this reaction, the techno-functional properties of caseins are also modified. As the negative charge of caseins was increased, succinylated caseins were 
more soluble at acidic pH values (Girerd et al. 1984). Vidal et al. (1998) studied the influence of the succinylation on the ability of caseins to form acid and rennet gels. They indicated a delay in the time of gelation and a decrease in the firmness of rennet gel. These modifications were related to a greater resistance of succinylated casein micelles to their aggregation. Lieske et al. (2000) also reported that succinylation of milk proteins increased the rennet gelation time and decreased the gel firmness. They explained these effects by (1) changes in the distribution of calcium between micellar and aqueous phase, (2) changes in the release of CMP during proteolysis, and (3) changes in the charge of casein micelles with release of individual casein molecules in the aqueous phase. Recently, Yang et al. (2014) reported that the solubility, emulsifying activity, and absorption at water-oil interface of succinylated caseins were enhanced, while their capacity to stabilize foam was reduced.

Acetylation or acylation The reaction of acetylation is performed by addition of acetic anhydride to caseins. The reaction results in a covalent attachment of acetate groups to amino groups of lysyl residues. Hoagland (1966) indicated that for a concentration of $25 \mathrm{mM}$ of added calcium, unmodified $\beta$-casein was totally precipitated whereas the acylated $\beta$-casein was soluble at 44\%. Vidal et al. (2002) reported an increase of micellar hydration without effect on the size and zeta potential of acylated casein micelles. In terms of techno-functionality, the acetylation of casein increased their heat stability (Creamer et al. 1971) and solubility at acid pH (Santos and Tomasula 2000).

\subsubsection{Phosphorylation}

Casein molecules are naturally phosphorylated, but it is interesting to add supplementary phosphorus to change their physico-chemical and functional properties. The chemical phosphorylation, performed in presence of phosphorus oxychloride $\left(\mathrm{POCl}_{3}\right)$, results in a covalent linking of phosphorus atoms to proteins (Matheis 1991). After their phosphorylation, caseins are more electronegative. As a consequence of this supplementary phosphorylation, the $\mathrm{pHi}$ and surface hydrophobicity of caseins were reduced (Medina et al. 1992; Sitohy et al. 1995). Due to the increase of the electronegativity of caseins after their phosphorylation, their foaming and emulsifying properties and also their solubility were improved (Girerd et al. 1984; Medina et al. 1992; Sitohy et al. 1995). Nevertheless, Matheis et al. (1983) showed that addition of 7.4 phosphate groups per mole of caseins increased their viscosity and capacity of water holding, but decreased their solubility and emulsification capacity.

\subsection{Enzymatic modifications}

\subsubsection{Dephosphorylation}

Dephosphorylation of phosphoseryl residues can occur naturally but phosphatase activity in milk is relatively limited (Molina et al. 2007). The dephosphorylation of casein can also be deliberately induced by addition of acid or alkaline phosphatases. However, studies with these enzymes are not always easy due to their residual proteolytic activity which can induce misinterpretation of the results. In addition, the 
extent of dephosphorylation depends on substrate and hydrolysis conditions (enzyme used, $\mathrm{pH}$, temperature, presence of inhibitors). The effects of dephosphorylation were mainly studied on purified casein molecules and secondarily on casein micelles. Lorient and Linden (1976) showed a preferential dephosphorylation of $\kappa$ - and $\beta$-caseins with purified milk alkaline phosphatase. According to Li-Chan and Nakai (1989), dephosphorylation reached 97,70 , and $90 \%$ for whole casein, $\alpha_{\mathrm{s} 1}$-casein, and $\beta$-casein, respectively. Nevertheless, Molina et al. (2007) indicated levels of dephosphorylation of $71.6,89.2$, and $73.7 \%$ for whole casein, $\alpha$-casein, and $\beta$-casein, respectively.

As phosphate groups are negatively charged, the dephosphorylation reduced the negative charge of casein. Consequently, this charge modification shifted the $\mathrm{pHi}$ value of caseins toward neutral $\mathrm{pH}$ and increased their solubility at acidic $\mathrm{pH}$ (Darewicz et al. 1999a). Recently, McCarthy et al. (2013) showed that dephosphorylation of $\beta$-casein increased its $\mathrm{pH}$ of minimum solubility from $\mathrm{pH} 5$ to 5.5. As other consequences of this dephosphorylation, the charge distribution along the protein chain was also altered affecting the auto-association of caseins. Besides, the calcium binding and precipitability in the presence of calcium were reduced (Pepper and Thompson 1963; Yamauchi et al. 1967; Bingham 1976; Molina et al. 2007; McCarthy et al. 2013). The loss of phosphate groups reduced the number of calcium bridges (Aoki et al. 1985). Formation of artificial micelles with dephosphorylated caseins was difficult because of the removal of the majority of calcium-binding sites (Pepper and Thompson 1963; Yamauchi et al. 1967; Bingham et al. 1972; Pearse et al. 1986; McCarthy et al. 2013) and resulted in the formation of abnormal micelles less stable in presence of calcium and smaller in size (Pepper and Thompson 1963; Knoop and Peters 1975; Pearse et al. 1986; Hiller and Lorenzen 2009).

Changes in the functional properties of dephosphorylated caseins are also described. The effects of dephosphorylation of caseins on their rennet coagulation were reported by several authors. They determined longer coagulation times for dephosphorylated casein (Yamauchi and Yoneda 1978; Reimerdes and Roggenbuck 1980; Pearse et al. 1986) than native ones. Moreover, the curd tensions were lower for rennet gels of dephosphorylated casein (Yamauchi and Yoneda 1978; Reimerdes and Roggenbuck 1980). The rennet gel was made up of smaller units of dephosphorylated casein unable to be self-associated into dense and uniform network. Consequently, a weak gel was formed (Van Hekken and Strange 1994). The micro-structure of acid curds made with native and dephosphorylated casein micelles showed also major differences (Li-Chan and Nakai 1989). Lorenzen and Reimerdes (1992) showed that dephosphorylation of $\alpha_{\mathrm{s}}$ - and $\beta$-casein stabilized the creaming behavior of oil/water emulsions. By molecular dynamics, Cassiano and Area (2003) reported that the affinity of totally dephosphorylated $\beta$-casein for water/lipid interface was lower than $\beta$-casein which was able to be inserted in the water/lipid interface.

\subsubsection{Deamidation}

The enzyme catalyzing the deamidation of glutamine in glutamic acid (with production of ammonium) is a protein glutaminase. This enzyme was discovered in the culture supernatant of Chryseobacterium proteolyticum (Yamaguchi and Yokoe 2000; Yamaguchi et al. 2001), and its action was investigated on several food proteins (Motoki et al. 1986; Gu et al. 2001; De Jong and Koppelman 2002; Yong et al. 
2004, 2006). On skim milk proteins, Miwa et al. (2010) showed that deamidation increased the electronegativity of caseins due to the formation of supplementary carboxyl groups leading to a reduction of the $\mathrm{pHi}$ toward lower $\mathrm{pH}$. Turbidity decreased until the milk became translucent. All these observations suggested that deamidation induced dissociation of casein micelles due to increase in the electrostatic repulsions between caseins and breaking of salt bridges. The particle size analysis and observations by transmission electron microscopy confirmed this destructuration of casein micelles by showing small particles in highly deamidated skim milk (Miwa et al. 2010).

Due to these physico-chemical changes, deamidation is an interesting method to improve solubility, emulsifying, foaming, and gelation properties of different food proteins (Hamada 1994). The solubility, viscosity, and emulsifying capacity of milk were improved with an increase of the deamidation degree (Miwa et al. 2010). Recently, Miwa et al. (2014) studied the effect of milk enzymatic deamidation on the textural and microstructural properties of yoghurts, and they highlighted a decrease in their firmness. In addition, syneresis on the surface of the yoghurt decreased while the surface appeared to be smooth and glossy. Authors attributed these structural modifications to the presence of more hydrophilic caseins with a low capacity to selfassociate, thereby decreasing the cohesive forces between casein.

\subsubsection{Reticulation}

Transglutaminase, used to reticulate food proteins, has a microbial origin and is recognized as safe. This enzyme cross-links covalently proteins between the $\gamma$ carboxyamide group of glutamine residues and the $\varepsilon$-amino group of lysyl residues (Jaros et al. 2006). This reaction is influenced by various parameters such as temperature, $\mathrm{pH}$, pressure, and type of milk proteins. Thus, Lorenzen et al. (1998) and Lorenzen (2002) showed that the degree of protein cross-linking decreased in the following order: sodium caseinate $>$ ultrafiltered skim milk powder $>$ skim milk powder $>$ whey protein isolate. These authors found that a decrease of only $5 \%$ of free amino groups was necessary to observe a complete oligomerization of caseins. Compared to sodium caseinate, the reaction of casein micelles with transglutaminase formed fewer amounts of polymers suggesting that casein molecules in sodium caseinate were more accessible and reactive for the reticulation than in casein micelles (Bönisch et al. 2004). Tang et al. (2005) indicated that the reactivity with transglutaminase of different casein molecules in sodium caseinate was in the following order: $k$-casein $>\alpha$-casein $>\beta$ casein. With casein micelles, the rate of cross-linking was different and decreased in the following order: $k$-casein $>\beta$-casein $>\alpha$-casein (Sharma et al. 2001; Smiddy et al. 2006; Hinz et al. 2007). By using dynamic light scattering, Mounsey et al. (2005) and Moon et al. (2009) found that the cross-linking induced by transglutaminase did not influence the micellar sizes suggesting intramicellar cross-linkings rather than intermicellar.

As expected, these cross-linking reactions led to modifications of functional properties of caseins such as solubility, emulsifying capacity, foaming, and gelation properties (Motoki et al. 1984; Nio et al. 1986; Faergemand and Qvist 1997; Nonaka et al. 1997; Faergemand et al. 1998; Ozer et al. 2007). Cross-linking of casein micelles improved their intra-micellar stability. Thus, cross-linked casein micelles were able to form nanogel particles more stable to heat-induced coagulation than normal casein 
micelles (O’Sullivan et al. 2002; Smiddy et al. 2006; Huppertz et al. 2007; Huppertz and de Kruif 2008). Due to the positive improvement of the functional properties of caseins, several patents describing the use of transglutaminase for the development of innovative dairy products have been published (Han et al. 2003; Kumazawa and Miwa 2005; Timmer-Keetels et al. 2012). The scientific literature is also rich of articles concerning the yogurt production using transglutaminase knowing that cross-linking of milk proteins might represent an interesting method for improving texture. Thus, Schey (2003) reported texture improvements of fermented dairy products by enzymatic cross-linking with transglutaminase with an increased gel strength, a reduced syneresis, a dry and smooth surface for set-style yogurt, or an improved viscosity and creaminess for stirred yogurt.

Other enzymes named tyrosinase and laccase could also cross-link milk proteins (Huppertz 2009), but no precise results concerning the modifications of casein structures and functions are described in the literature.

\subsubsection{Deglycosylation}

$\mathrm{K}$-Casein is a hydrophilic and negatively charged protein. Due to these characteristics, this casein is located on the micellar surface and stabilizes the micellar structure by steric hindrance and electrostatic repulsions (Horne 1986; Walstra 1990; Holt and Horne 1996; Dziuba and Minkiewicz 1996). These properties are partly due to the presence of different sugar residues like $\mathrm{N}$-acetylneuraminic acid (NANA). Minkiewicz et al. (1993) studied the influence of this carbohydrate by using neuraminidase which can liberate up to $85 \%$ of NANA linked to $\mathrm{k}$-casein. The authors have compared the deglycosylated casein against native casein and indicated no significant difference in their structure, size distribution, and property to be coagulated by rennet. In contrast, they determined smaller heat stability for modified casein. Difference in the rennin-gel structure for deglycosylated casein was also observed with the observation of larger cluster and pores in comparison with native casein. With the same objective, Cases et al. (2003) deglycosylated also casein micelles by neuraminidase and studied the physico-chemical properties and their ability to form acid gel. They indicated that partial deglycosylation $(\sim 85 \%)$ did not significantly affect neither the partition of molecules of casein between aqueous and micellar phases nor their charge and hydration. In the same time, they showed a shorter acid gelation time and a higher final firmness for the deglycosylated casein micelles. This enhancement could be due to the increase of hydrophobic sites on the micellar surface after their deglycosylation.

More recently, Jacobsen et al. (2014) found that after treatment with N-glycosidaseF, yoghurt gel firmness increased. This effect was stable over a period of 28 days. Moreover, a sensory panel described that the yoghurts have an improved thickness.

\subsubsection{Proteolysis}

Proteolysis is also an interesting method to modify casein structure in order to enhance their functional properties. The relationship between enzymatic hydrolysis and structural change of casein is studied since several years (Lee et al. 1987; Haque 1993; Panyam and Kilara 1996; Chobert et al. 1998; Slattery and Fitzgerald 1998; Gastaldi et al. 2003; Banach et al. 2013; Wang et al. 2013; Luo et al. 2014). From a general point 
of view, proteolysis of caseins induces (1) decrease in their molecular weight, (2) increase in the number of ionized groups $\left(\mathrm{NH}_{3}{ }^{+}\right.$and $\left.\mathrm{COO}^{-}\right)$, and (3) conformational

Table 4 Methods modifying the charge of casein

\begin{tabular}{|c|c|c|}
\hline Methods & Main biochemical consequences & $\begin{array}{l}\text { Electrical charge } \\
\text { of caseins }\end{array}$ \\
\hline Heat treatment & $\begin{array}{l}\text { - Blockage of lysyl residues by lactose } \\
\text { - Covalent binding of } \beta \text {-lactoglobulin } \\
\text { - Precipitation of calcium phosphate }\end{array}$ & Less negative \\
\hline Cooling & $\begin{array}{l}\text { - Solubilization of micellar calcium } \\
\text { phosphate } \\
\text { - Solubilization of } \beta \text {-casein }\end{array}$ & ND \\
\hline High pressure & - Disruption of casein micelles & ND \\
\hline Ultrasounds & - Disruption of casein micelles & ND \\
\hline $\mathrm{pH}$ decrease (6.7 to 4.6$)$ & $\begin{array}{l}\text { - Protonation of casein } \\
\text { - Decrease of cations-casein interactions }\end{array}$ & Less negative \\
\hline $\mathrm{pH}$ increase (6.7 to 9.0$)$ & $\begin{array}{l}\text { - Increase of the casein ionization } \\
\text { - Insolubilization of calcium phosphate }\end{array}$ & More negative \\
\hline Addition of divalent cations & $\begin{array}{l}\text { - Direct association of added cation } \\
\text { to casein } \\
\text { - Association of cation-inorganic } \\
\text { phosphate to casein micelles } \\
\text { - Increase of ionic strength }\end{array}$ & Less negative \\
\hline Addition of $\mathrm{NaCl}$ & $\begin{array}{l}\text { - Solubilization of micellar calcium } \\
\text { - Increase of ionic strength }\end{array}$ & No effect \\
\hline $\begin{array}{l}\text { Micro- or ultrafiltration combined } \\
\text { with diafiltration }\end{array}$ & $\begin{array}{l}\text { - Removal of diffusible ions } \\
\quad \text { (decrease of shielding charge) }\end{array}$ & More negative \\
\hline Addition of calcium chelatant & $\begin{array}{l}\text { - Decrease in casein-calcium interaction } \\
\text { - Solubilization of micellar calcium } \\
\text { phosphate }\end{array}$ & More negative \\
\hline Addition of external compounds & $\begin{array}{l}\text { - Binding to casein by hydrophobic } \\
\text { and hydrogen bonding }\end{array}$ & ND \\
\hline Glycation/lactosylation & - Blockage of lysyl residues & More negative \\
\hline Chemical reticulation by genipin & - Blockage of lysyl residues & More negative \\
\hline Succinylation & - Blockage of lysyl residues & More negative \\
\hline Acetylation & - Blockage of lysyl residues & More negative \\
\hline Chemical phosphorylation & - Addition of phosphate & More negative \\
\hline Dephosphorylation & $\begin{array}{l}\text { - Removal of organic phosphate from } \\
\text { phosphoseryl residues }\end{array}$ & Less negative \\
\hline Deamidation & $\begin{array}{l}\text { - Release of ammonia from glutamine } \\
\text { transformed in glutamic residues }\end{array}$ & More negative \\
\hline Reticulation by transglutaminase & $\begin{array}{l}\text { - Cross-link between lysyl and } \\
\text { glutamine residues }\end{array}$ & More negative \\
\hline Deglycosylation of $\mathrm{K}$-casein by neuraminidase & - Release of NANA & No effect \\
\hline Proteolysis of $\mathrm{k}$-casein by chymosin & $\begin{array}{c}\text { - Release of caseinomacropeptide } \\
\text { (106-169) negatively charged }\end{array}$ & $\begin{array}{l}\text { Less negative for } \\
\text { peptide } 1-105\end{array}$ \\
\hline
\end{tabular}

Charge of casein molecules or casein micelle is determined by evaluation of their zeta potential $N D$ not determined 
change with exposure of hydrophobic groups. As results of this proteolytic degradation, size, isoelectric point, and molecular flexibility of caseins alter their techno-functionalities. Generally, the solubility at the isoelectric point of caseins increases with hydrolysis (Chobert et al. 1988; Chobert 2012). For the other techno-functionalities, there is no clear relationship with proteolysis. Proteolysis of caseins can improve as well as reduce their emulsifying and foaming properties. This difficulty is due to the complexity of the proteolysis. Indeed, its intensity (number of produced peptides) and its quality (nature of produced peptides) depend on several factors like (1) quality of substrates (milk proteins, casein micelles, purified casein molecules, etc.); (2) environmental conditions; (3) time of hydrolysis; (4) type/specificity of enzyme used such as bovine and camel chymosin, trypsin, chymotrypsin, plasmin, papain, pronase, alcalase, neutrase, pepsin, thermolysin, pancreatine, plant enzymes, microbial enzymes, etc.; and (5) enzyme/substrate ratio. Among all these enzymes modifying the structure-function of casein micelle, one of the most remarkable is chymosin because it can destabilize casein micelle mainly with the cutting of the 105-106 peptidic bond of $\mathrm{K}$-casein. This destabilization occurs when $90 \%$ of this bond is cut and corresponds to the release of caseinomacropeptide with concomitant decreases in electrostatic repulsion and steric hindrance between casein micelles. It can also be interesting to use it but in a controlled way to initiate destabilization of casein micelles without observing coagulation. Thus, Gastaldi et al. (2003) studied the effects of controlled K-casein hydrolysis (19, 35, and $51 \%$ ) on the physico-chemical properties of casein micelles and their rheological properties of acid milk gels. Decreases in zeta potential, hydrodynamic diameter, and micellar hydration with the level of K-casein hydrolysis were observed. In the same time, these authors determined increases in $\mathrm{pH}$ of gelation, loss tangent, and serumholding capacity of acid gels with increasing the degree of $\mathrm{K}$-casein hydrolysis.

\section{Conclusion}

For several decades, the scientific community has been working to describe and understand the complexity of casein micelles in terms of composition, structure, and functional properties. For that purpose, different approaches in chemistry, biochemistry, biology, biophysics, and physics have been used. Today, the plasticity of casein is admitted and a lot of results describing the different structures of native and modified molecules of casein and casein micelles have been published. The structure of the molecules of casein alone or of caseins organized under micellar form can be modulated according to their physico-chemical environment or through their direct modifications performed by chemical or enzymatic actions. The consequences of these structural modifications induce techno-functional modifications relatively well described. Among all data reported in this article, the charge is one key factor responsible for the structure-function of casein molecules or casein micelles. Table 4 reports the methods described in this paper to modify positively or negatively this parameter.

One of the consequences of the charge modification is a change of the hydrophilicity/hydrophobicity balance affecting the techno-functionality of caseins. In spite of this intense research, it is necessary to improve our knowledge on structures, organizations, and techno-functionalities of these neo-formed micellar structures. It is a real challenge for scientific community but also for the dairy industry. Today, the 
number of food applications for modified casein micelle is low but could be very high. As written in this review, physical, chemical, and enzymatic methods can be used to modify casein micelles. New technologies or combination of methods could be interesting for creating new and innovative micellar functionalities. Due to its abundance and its relative ease to isolate casein, their potential to be used in food as described in this paper and non-food applications could be enlarged. Non-food uses of caseins include glue, wool, bone, film, and component for TV tubes (de Kruif 2003). Different publications also relate the use of casein micelles as vehicles for bioactive substances (Livney 2010).

Conflict of interest F. Gaucheron and C. Broyard declare that they have no conflict of interest.

Compliance with ethics requirement statements This article does not contain any studies with human or animal subjects performed by any of the authors.

\section{References}

Ahmad S, Piot M, Rousseau F, Grongnet JF, Gaucheron F (2009) Physico-chemical changes in casein micelles from buffalo and cow's milk as a function of alkalinisation. Dairy Sci Technol 89:387-403

Alexander M, Nieha MP, Ferrer MA, Corredig M (2011) Changes in the calcium cluster distribution of ultrafiltered and diafiltered fresh skim milk as observed by small angle neutron scattering. J Dairy Res 78 : 349-356

Anema SG, Li Y (2003) Effect of $\mathrm{pH}$ on the association of denatured whey proteins with casein micelles in heated reconstituted skim milk. J Agric Food Chem 51:1640-1646

Aoki T, Toyooka K, Kako Y (1985) Role of phosphate groups in the calcium sensitivity of $\alpha_{\mathrm{s} 2 \text {-casein. J Dairy }}$ Sci 68:1624-1629

Augustin MA, Clarke PT (2008) Skim milk powders with enhanced foaming and steam-frothing properties. Dairy Sci Technol 88:149-161

Augustin MA, Udabage P (2007) Influence of processing on functionality of milk and dairy proteins. Adv Food Nutr Res 43:1-38

Banach JC, Lin Z, Lamsal BP (2013) Enzymatic modification of milk protein concentrate and characterization of resulting functional properties. LWT - Food Sci Technol 54:397-403

Benzaria A, Maresca M, Taieb N, Dumay E (2013) Interaction of curcumin with phosphocasein micelles processed or not by dynamic high-pressure. Food Chem 138:2327-2337

Bhatt H, Cucheval A, Coker C, Patel H, Carr A, Bennett R (2014) Effect of lactosylation on plasmin-induced hydrolysis of $\beta$-casein. Int Dairy J 38:213-218

Bingham EW (1976) Modification of casein by phosphatases and protein kinases. J Agric Food Chem 24: 1094-1099

Bingham EW, Farrell HM, Carroll RJ (1972) Properties of dephosphorylated $\alpha_{s_{1}}$-casein. Precipitation by calcium ions and micelle formation. Biochemistry 11:2450-2454

Bönisch MP, Lauber S, Kulozik U (2004) Effect of ultra-high temperature treatment on the enzymatic crosslinking of micellar casein and sodium caseinate by transglutaminase. J Food Sci 69:398-404

Bouchoux A, Gésan-Guiziou G, Pérez J, Cabane B (2010) How to squeeze a sponge: casein micelles under osmotic stress, a SAXS study. Biophys J 99:3754-3762

Bravo FI, Felipe X, López-Fandiño R, Molina E (2013) High-pressure treatment of milk in industrial and pilot-scale equipments: effect of the treatment conditions on the protein distribution in different milk fractions. Eur Food Res Technol 236:499-506

Buccheim W, Prokopeck D (1992) Die Hochdruckbehandlung: ein alternatives Verfahren zur Haltbarmachung und Bearteitung von Milch und anderen Lebensmitteln. Dtsch Milchwirtsch 43:1374-1376

Cases E, Vidal V, Cuq JL (2003) Effect of $\alpha$-casein deglycosylation on the acid coagulability of milk. J Food Sci 68:2406-2410

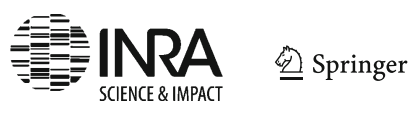


Casiraghi E, Lucisano M (1991) Rennet coagulation of milk retentates. Effect of the addition of sodium chloride and citrate before ultrafiltration. Milchwissenchaft 46:775-778

Cassiano MM, Area JAG (2003) Dependence of the interfacial behavior of $\beta$-casein on phosphoserine residues. J Dairy Sci 86:3876-3880

Chaubaroux C, Vrana E, Debry C et al (2012) Collagen-based fibrillar multilayer films cross-linked by a natural agent. Biomacromolecules 13:2128-2135

Chevalier-Lucia D, Blayo C, Gràcia-Julià A, Picart-Palmade L, Dumay E (2011) Processing of phosphocasein dispersions by dynamic high pressure: effects on the dispersion physico-chemical characteristics and the binding of $\alpha$-tocopherol acetate to casein micelles. Innov Food Sci Emerg Technol 12:416-425

Chobert JM (2012) Milk protein tailoring to improve functional and biological properties. J Bio Sci Biotech 1: 171-197

Chobert JM, Bertrand-Harb C, Nicolas MG (1988) Solubility and emulsifying properties of caseins and whey proteins modified enzymically by trypsin. J Agric Food Chem 36:883-892

Chobert JM, Tran V, Haertlé T (1998) How the substitution of K188 of trypsin binding site by aromatic amino acids can influence the processing of $\beta$-casein. Biochemical and biophysical research communications 246(3):847-858

Closs B, Courthaudon JL, Lorient D (1990) Effect of chemical glycosylation on the surface properties of the soluble fraction of casein. J Food Sci 55:437-439

Colas B, Gobin C, Lorient D (1988) Viscosity and voluminosity of caseins chemically modified by reductive alkylation with reducing sugars. J Dairy Res 55:539-546

Corzo-Martinez M, Moreno FJ, Villamiel M, Harte FM (2010) Characterization and improvement of rheological properties of sodium caseinate glycated with galactose, lactose and dextran. Food Hydrocoll 24:88-97

Courthaudon JL, Colas B, Lorient D (1989) Covalent binding of glycosyl residues to bovine casein: effects on solubility and viscosity. J Agric Food Chem 37:32-36

Creamer LK, Roeper J, Lohrey EH (1971) Preparation and evaluation of some acid soluble casein derivatives. N Z J Dairy Sci Technol 6:107

Creamer LK, Berry GP, Mills OE (1977) A study of the dissociation of $\beta$-casein from the bovine casein micelle at low temperature. N Z J Dairy Sci Technol 12:58-66

Dalgleish DG (2011) On the structural models of bovine casein micelles - review and possible improvements. Soft Matter 7:2265-2272

Dalgleish DG, Corredig M (2012) The structure of the casein micelle of milk and its changes during processing. Ann Rev Food Sci Technol 3:449-467

Dalgleish DG, Law AJR (1988) pH-induced dissociation of bovine casein micelles. I. Analysis of liberated caseins. J Dairy Res 55:529-538

Dalgleish DG, Law AJR (1989) pH-induced dissociation of bovine casein micelles. II. Mineral solubilization and its relation to casein release. J Dairy Res 56:727-735

Dalgleish DG, Spagnuolo PA, Goff HD (2004) A possible structure of the casein micelle based on highresolution field-emission scanning electron microscopy. Int Dairy J 14:1025-1031

Dalsgaard TK, Nielsen JH, Larsen LB (2007) Proteolysis of milk proteins lactosylated in model systems. Mol Nutr Food Res 51:404-414

Darewicz M, Dziuba J, Mioduszewska H, Minkiewicz P (1999a) Modulation of physico-chemical properties of bovine $\beta$-casein by nonenzymatic glycation associated with enzymatic dephosphorylation. Acta Aliment Hung 28:339-354

Darewicz M, Dziuba J, Mioduszewska H (1999b) Some physico-chemical properties and structural changes of bovine $\beta$-casein upon glycation. Nahrung 42:213-214

Davies DT, White JCD (1960) The use of ultrafiltration and dialysis in isolating the aqueous phase of milk and in determining the partition of milk constituents between the aqueous and disperse phases. J Dairy Res 27 : $171-190$

De Jong GAH, Koppelman SJ (2002) Transglutaminase catalyzed reactions: impact on food applications. J Food Sci 67:2798-2806

De Kort E, Minor M, Snoeren T, van Hooijdonk T, van der Linden E (2011) Effect of calcium chelators on physical changes in casein micelles in concentrated micellar casein solutions. Int Dairy J 21:907-913

De Kruif CG (1997) Skim milk acidification. J Colloid and Interface Sci 185:19-25

De Kruif CG (2003) Non-food applications of caseins. In WY Aalbersberg, RJ Hamer, P Jasperse, HHJ de Jongh, CG de Kruif, P Walstra, FA de Wolf (eds) Progress in biotechnology: industrial proteins in perspective, Vol. 23 (pp. 259-263, 269). Amsterdam: Elsevier Science Ltd 
De Kruif CG, Holt C (2003) Casein micelle structure functions and interactions 1. In Fox, P. F., McSweeney, P. L. H., Eds.; Advanced dairy chemistry-proteins part A, 3rd edn. Kluwer Academic/Plenum Publishers: New York, Vol. 1, pp 233-276

De Kruif CG, Huppertz T, Urban VS, Petukhov AV (2012) Casein micelles and their internal structure. Adv Colloid Interface Sci 171:36-52

Desobry-Banon S, Richard F, Hardy J (1994) Study of acid and rennet coagulation of high pressurised milk. J Dairy Sci 77:3267-3274

Dickinson E (2006) Structure formation in casein-based gels, foams, and emulsions. Colloids Surfaces A: Physicochem Eng Asp 288:3-11

Donato L, Guyomarc'h F (2009) Formation and properties of the whey protein/K-casein complexes in heated skim milk—a review. Dairy Sci Technol 89:3-29

Downey WK, Murphy RF (1970) The temperature-dependent dissociation of $\beta$-casein from bovine casein micelles and complexes. J Dairy Res 37:361-372

Dziuba J, Minkiewicz P (1996) Influence of glycosylation on micelle-stabilizing ability and biological properties of C-terminal fragments of cow's K-casein. Int Dairy J 6:1017-1044

Endo TOHR, Taguchi HEIH (1973) The constituents of Gardenia jasminoides geniposide and genipingentiobioside. Chem Pharm Bull (Tokyo) 21:2684-2688

Evangelisti F, Calcagno C, Zunin P (1994) Relationship between blocked lysine and carbohydrate composition of infant formulas. J Food Sci 59:335-337

Faergemand M, Qvist KB (1997) Transglutaminase: effect on rheological properties, microstructure and permeability of set style acid skim milk gels. Food Hydrocoll 11:287-292

Faergemand M, Otte J, Qvist KB (1998) Emulsifying properties of milk proteins cross-linked with microbial transglutaminase. Int Dairy J 8:715-723

Famelart MH, Lepesant F, Gaucheron F, Le Graët Y, Schuck P (1996) pH-induced physicochemical modifications of native phosphocaseinate suspensions: influence of aqueous phase. Lait 76:445-460

Famelart MH, Gaucheron F, Mariette F, Le Graët Y, Raulot K, Boyaval E (1998) Acidification of pressuretreated milk. Int Dairy J 7:325-330

Famelart MH, Le Graët Y, Raulot K (1999) Casein micelle dispersions into water, $\mathrm{NaCl}$ and $\mathrm{CaCl}_{2}$ : physicochemical characteristics of micelles and rennet coagulation. Int Dairy J 9:293-297

Ferrer M, Alexander M, Corredig M (2014) Changes in the physico-chemical properties of casein micelles during ultrafiltration combined with diafiltration. LWT Food Sci Technol 59:173-180

Foegeding AE, Davis JP (2011) Food protein functionality: a comprehensive approach. Food Hydrocoll 25 : 1853-1864

Fox PF, Brodkorb A (2008) The casein micelle: historical aspects, current concepts and significance. Int Dairy J 18:677-684

Fox PF, McSweeney PL (1998) Dairy chemistry and biochemistry. Blackie Academic and Professional Publishers, London

Fox PF, Mulvihill DM (1983) Functional properties of caseins, caseinates and casein co-precipitates. In: Physico-chemical aspects of dehydrated protein-rich milk products, IDF Symposium, Helsingor, Denmark, Statens Forsogsmejeri, Hillerod, Denmark (pp. 188-259)

Gastaldi E, Trial N, Guillaume C, Bourret E, Gontard N, Cuq JL (2003) Effect of controlled k-casein hydrolysis on rheological properties of acid milk gels. J Dairy Sci 86:704-711

Gaucheron F (2001) Heat-induced deamidation of casein molecules: influence of physicochemical conditions. Milchwissenchaft 56:183-187

Gaucheron F (2004a) Interactions caséines-cations. In: "Minéraux et produits laitiers", Editions Tec et Doc, Paris. pp 81-112

Gaucheron F (2004b) Minéraux et produits laitiers. Tec \& Doc, Paris

Gaucheron F (2005) The minerals of milk. Reprod Nutr Dev 45:473-483

Gaucheron F, Famelart MH, Le Graët Y (1996) Iron- supplemented caseins: preparation physicochemical characterization and stability. J Dairy Res 63:233-243

Gaucheron F, Famelart MH, Mariette F, Raulot K, Michel F, Le Graët Y (1997a) Combined effects of temperature and high pressure treatments on physicochemical characteristics of skim milk. Food Chem 59:439-447

Gaucheron F, Le Graët Y, Raulot K, Piot M (1997b) Physicochemical characterization of iron-supplemented skim milk. Int Dairy J 7:141-148

Gaucheron F, Le Graët Y, Boyaval E, Piot M (1997c) Binding of cations to casein molecules: importance of physicochemical conditions. Milchwissenchaft 52:322-327

Gaucheron F, Le Graët Y, Briard V (2000) Effect of $\mathrm{NaCl}$ addition on the mineral equilibrium of concentrated and acidified casein micelles. Milchwissenchaft 55:82-86 
Gaucheron F, Mollé D, Pannetier R (2001) Influence of pH on the heat-induced proteolysis of casein molecules. J Dairy Res 68:71-80

Girerd E, Martin JE, Mesnier D, Lorient D (1984) Influence des modifications chimiques de la caséine sur ses propriétés fonctionnelles. Sci Alim 4:251-257

Grufferty MB, Fox PF (1985) Effect of added NaCl on some physicochemical properties of milk. Ir J Food Sci Technol 9:1-9

Gu YS, Matsumura Y, Yamaguchi S, Mori T (2001) Action of protein-glutaminase on $\alpha$-lactalbumin in the native and molten globule states. J Agric Food Chem 49:5999-6005

Guillaume C, Jimenez L, Cuq JL, Marchesseau S (2004) An original pH-reversible treatment of milk to improve rennet gelation. Int Dairy J 14:305-311

HadjSadok A, Pitkowski A, Nicolai T, Benyahia L, Moulai-Mostefa N (2008) Characterisation of sodium caseinate as a function of ionic strength, $\mathrm{pH}$ and temperature using static and dynamic light scattering. Food Hydrocoll 22:1460-1466

Hamada JS (1994) Deamidation of food proteins to improve functionality. Crit Rev Food Sci Nutr 34:283-292

Han XQ, Pfeifer JK, Lincourt RH, Schuerman JM (2003) Process for making a cheese product using transglutaminase. U.S. Patent 6572901 B2

Haque ZU (1993) Influence of milk peptides in determining the functionality of milk proteins: a review. J Dairy Sci 76:311-320

Haratifar S, Corredig M (2014) Interactions between tea catechins and casein micelles and their impact on renneting functionality. Food Chem 143:27-32

Harbourne N, Jacquier JC, O'Riordan D (2011) Effects of addition of phenolic compounds on the acid gelation of milk. Int Dairy J 21:185-191

Hiller B, Lorenzen PC (2009) Effect of phosphatase/transglutaminase treatment on molar mass distribution and techno-functional properties of sodium caseinate. LWT Food Sci Technol 42:87-92

Hinz K, Huppertz T, Kulozik U, Kelly AL (2007) Influence of enzymatic cross-linking on milk fat globules and emulsifying properties of milk proteins. Int Dairy J 17:289-293

Hoagland PD (1966) Acylated $\beta$-caseins: electrostatic interactions and aggregation. J Dairy Sci 49: 783-787

Holt C (1992) Structure and stability of bovine casein micelles. Adv Protein Chem 43:63-151

Holt C (1995) Effect of heating and cooling on the milk salts and their interaction with casein, In PF Fox, ed.: Heat induced changes in milk. International Dairy Federation, special issue No.9501, Bruxelles, pp 105133

Holt C (1997) The milk salts and their interaction with casein. In: Fox PF, Chapman \& Hall: Advanced dairy chemistry, volume 3, lactose, water, salts and vitamins, 2nd ed., London, pp. 233-256

Holt C, Horne DS (1996) The hairy casein micelle: evolution of the concept and its implications for dairy technology. Neth Milk Dairy J 50:85-111

Holt C, Carver J, Ecroyd H, Thorn DC (2013) Caseins and the casein micelle: their biological functions, structures, and behavior in foods. J Dairy Sci 96:6127-6146

Horne DS (1986) Steric stabilization and casein micelle stability. J Coll Interface Sci 111:250-260

Horne DS (1999) Formation and structure of acidified milk gels. Int Dairy J 9:261-268

Huppertz T (2009) Novel applications of enzymes in the dairy sector: optimizing functional properties of milk proteins by enzymatic cross-linking. In: Corredig M Ed.: Dairy-derived ingredients, food and nutraceutical uses. Woodhead Publishing Limited and CRC Press, pp 394 416

Huppertz T, De Kruif CG (2008) Structure and stability of nanogel particles prepared by internal cross-linking of casein micelles. Int Dairy J 18:556-565

Huppertz T, Fox PF (2006) Effect of $\mathrm{NaCl}$ on some physico-chemical properties of concentrated bovine milk. Int Dairy J 16:1142-1148

Huppertz T, Kruif D (2007) Disruption and reassociation of casein micelles during high pressure treatment: influence of whey proteins. J Dairy Res 74:194-197

Huppertz T, Fox PF, Kelly AL (2004a) High pressure treatment of bovine milk: effect on casein micelles and whey proteins. J Dairy Res 71:97-106

Huppertz T, Fox PF, Kelly AL (2004b) Properties of casein micelles in high pressure-treated bovine milk. Food Chem 87:103-110

Huppertz T, Smiddy MA, De Kruif CG (2007) Biocompatible micro-gel particles from cross-linked casein micelles. Biomacromolecules 8:1300-1305

Huppertz T, Vaia B, Smiddy MA (2008) Reformation of casein particles from alkaline-disrupted casein micelles. J Dairy Res 75:44-47

Hussain R, Gaiani C, Aberkane L, Scher J (2011a) Characterization of high-milk-protein powders upon rehydration under various salt concentrations. J Dairy Sci 94:14-23 
Hussain R, Gaiani C, Scher J (2011b) Revealing casein micelle dispersion under various ranges of $\mathrm{NaCl}$ : evolution of particles size and structure. World Acad Sci Eng Technol 73:972-976

Ichilczyk-Leone J, Amram Y, Scheind N, Lenoir J (1981) Le refroidissement du lait et son comportement en fromagerie. I. Incidences du refroidissement du lait sur ses caractères physico-chimiques et son comportement vis-à-vis de la présure. Rev Lait Fr 401:7-18

Jacobsen J, Wind SL, Rasholt EL, van den Brink JM (2014) N-Glycosidase F improves gel firmness in fermented milk products. Int Dairy J 38:169-173

Jaros D, Partschefeld C, Henle T, Rohm H (2006) Transglutaminase in dairy products: chemistry, physics, applications. J Texture Stud 37:113-155

Johnston DE, Murphy RJ (1993) Effects of some calcium-chelating agents on the physical properties of acidset milk gels. J Dairy Res 59:197-208

Johnston DE, Austin BA, Murphy RJ (1992) Effects of high pressure on milk. Milchwissenschaft 47:760-763

Kaliappan S, Lucey JA (2011) Influence of mixtures of calcium-chelating salts on the physicochemical properties of casein micelles. J Dairy Sci 94:4255-4263

Karlsson AO, Ipsen R, Shrader K, Ardo Y (2005) Relationship between physical properties of casein micelles and rheology of skim milk concentrate. J Dairy Sci 88:3784-3797

Kartsova LA, Alekseeva AV (2008) Effect of milk caseins on the concentration of polyphenolic compounds in tea. J Anal Chem 63:1107-1111

Kelly PM, Burgess KJ (1978) Foaming properties of milk protein concentrate prepared by ultrafiltration. Ir J Food Sci Technol 2:93-104

Kethireddipalli P, Hill AR, Dalgleish DG (2010) Protein interactions in heat-treated milk and effect on rennet coagulation. Int Dairy J 20:838-843

Knoop AM, Peters KH (1975) Phosphatase activity in acidified milk. Milchwissenschaft 30:674-680

Koutina G, Knudsen JC, Andersen U, Skibsted LH (2014) Temperature effect on calcium and phosphorus equilibria in relation to gel formation during acidification of skim milk. Int Dairy J 36:65-73

Kumazawa Y, Miwa N (2005) Process for producing cheese curd. U.S. Patent 2005/0123645 A1

Lakkis J, Villota R (1992) Effect of acylation on substructural properties of proteins: a study using fluorescence and circular dichroism. J Agric Food Chem 40:553-560

Le Graët Y, Brulé G (1993) Equilibres minéraux du lait: influence du pH et de la force ionique. Lait 73:51-60

Le Graët Y, Gaucheron F (1999) pH-induced solubilization of minerals from casein micelles: influence of casein concentration and ionic strength. J Dairy Res 66:215-224

Le Ray C, Maubois JL, Gaucheron F, Brulé G, Pronnier P, Garnier F (1998) Heat stability of reconstituted casein micelle dispersions: changes induced by salt addition. Lait 78:375-390

Le TT, Holland JW, Bhandari B, Alewood PF, Deeth HC (2013) Direct evidence for the role of Maillard reaction products in protein cross-linking in milk powder during storage. Int Dairy J 31:83-91

Lee SW, Shimizu M, Kaminogawa S, Yamauchi K (1987) Emulsifying properties of peptides obtained from the hydrolysates of $\beta$-casein. Agric Biol Chem 51:161-166

Li-Chan E, Nakai S (1989) Enzymatic dephosphorylation of bovine casein to improve acid clotting properties and digestibility for infant formula. J Dairy Res 56:381-390

Lieske B (1999) Effects of succinylation on selected physico-chemical properties on native casein micelles in milk. Milchwissenchaft 54:623-627

Lieske B, Konrad G, Faber W (2000) Effects of succinylation on the renneting properties of raw milk. Milchwissenchaft 55:71-74

Liu J, Ru Q, Ding Y (2012) Glycation a promising method for food protein modification: physicochemical properties and structure, a review. Food Res Int 49:170-183

Liu DZ, Weeks MG, Dunstan DE, Martin GJO (2013) Temperature-dependent dynamics of bovine casein micelles in the range $10-40{ }^{\circ} \mathrm{C}$. Food Chem 141:4081-4086

Liu XT, Zhang H, Wang F, Luo J, Guo HY, Ren FZ (2014a) Rheological and structural properties of differently acidified and renneted milk gels. J Dairy Sci 97:3292-3299

Liu Z, Juliano P, Williams RPW, Niere J, Augustin MA (2014b) Ultrasound effects on the assembly of casein micelles in reconstituted skim milk. J Dairy Res 81:146-155

Liu Z, Juliano P, Williams RPW, Niere J, Augustin MA (2014c) Ultrasound improves the renneting properties of milk. Utrason Sonochem 21:2131-2137

Livney YD (2010) Milk proteins as vehicles for bioactives. Curr Opin Colloid Interface Sci 15:73-83

Lorenzen PC (2002) Enzymatic crosslinking of dairy proteins. In: New processing technologies for the future. Proceedings of the Emerging Technologies Conference, Auckland, New Zealand. International Dairy Federation, pp. 30-36

Lorenzen PC, Reimerdes EH (1992) Enzymatic dephosphorylation of caseins and creaming behaviour of o/w emulsions stabilized with dephosphorylated casein fractions. Nahrung 36:595-599

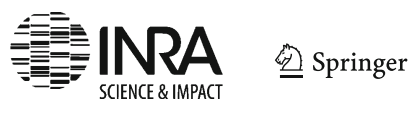


Lorenzen PC, Schlimme E, Roos N (1998) Crosslinking of sodium caseinate by a microbial transglutaminase. Nahrung 42:151-154

Lorient D, Linden G (1976) Dephosphorylation of bovine casein by milk phosphatase. J Dairy Res 43:19-26

Lucey JA, Tamehana M, Singh H, Munro PA (2001) Effect of heat treatment on the physical properties of milk gels made with both rennet and acid. Int Dairy J 11:559-565

Luo Y, Pan K, Zhong Q (2014) Physical, chemical and biochemical properties of casein hydrolyzed by three proteases: partial characterizations. Food Chem 155:146-154

Madadlou A, Mousavi ME, Emam-djomeh Z, Ehsani M, Sheehan D (2009) Sonodisruption of re-assembled casein micelles at different $\mathrm{pH}$ values. Ultrason Sonochem 16:644-648

Madadlou A, Emam-Djomeh Z, Mousavi ME, Mohamadifar M, Ehsani M (2010) Acid-induced gelation behavior of sonicated casein solutions. Ultrason Sonochem 17:153-158

Marchin S, Putaux JL, Pignon F, Léonil J (2007) Effects of the environmental factors on the casein micelle structure studied by cryo transmission electron microscopy and small-angle x-ray scattering/ultrasmallangle x-ray scattering. J Chem Phys 126:045101

Matheis G (1991) Phosphorylation of food proteins with phosphorus oxychloride-improvement of functional and nutritional properties: a review. Food Chem 39:13-26

Matheis G, Penner MH, Feeney RE, Whitaker JR (1983) Phosphorylation of casein and lysozyme by phosphorus oxychloride. J Agric Food Chem 31:379-387

McCarthy NA, Kelly AL, O’Mahony JA, Fenelon MA (2013) The physical characteristics and emulsification properties of partially dephosphorylated bovine $\beta$-casein. Food Chem 138:1304-1311

McMahon DJ, Du H, McManus WR, Larsen KM (2009) Microstructural changes in casein supramolecules during acidification of skim milk. J Dairy Sci 92:5854-5867

Medina AL, Colas B, Le Meste M, Renaudet I, Lorient D (1992) Physicochemical and dynamic properties modified by chemical phosphorylation. J Food Sci 57:617-620

Mekmene O, Le Graët Y, Gaucheron F (2009) A model for predicting salt equilibria in milk and mineralenriched milks. Food Chem 116:233-239

Mekmene O, Le Graët Y, Gaucheron F (2010) Theoretical model for calculating ionic equilibria in milk as a function of $\mathrm{pH}$ : comparison to experiment. J Agric Food Chem 58:4440-4447

Menéndez-Aguirre O, Stuetz W, Grune T, Kessler A, Weiss J, Hinrichs J (2011) High pressure-assisted encapsulation of vitamin D2 in reassembled casein micelles. High Pressure Res 31:265-274

Menéndez-Aguirre O, Kessler A, Stuetz W, Grune T, Weiss J, Hinrichs J (2014) Increased loading of vitamin $\mathrm{D}_{2}$ in reassembled casein micelles with temperature-modulated high pressure treatment. Food Res Int 64: 74-80

Merel-Rausch E, Kulozik U, Hinrichs J (2007) Influence of pressure release rate and protein concentration on the formation of pressure-induced casein structures. J Dairy Res 74:283-289

Minkiewicz P, Dziuba J, Muzinska B (1993) The contribution of N-acetylneuraminic acid in the stabilization of micellar casein. Pol J Food Nutr Sci 2(43):39-48

Miwa N, Yokoyama K, Wakabayashi H, Nio N (2010) Effect of deamidation by protein-glutaminase on physicochemical and functional properties of skim milk. Int Dairy J 20:393-399

Miwa N, Nio N, Somoto K (2014) Effect of enzymatic deamidation by protein-glutaminase on the textural and microstructural properties of set yoghurt. Int Dairy J 36:1-5

Mizuno R, Lucey JA (2005) Effects of emulsifying salts on the turbidity and calcium-phosphate-protein interactions in casein micelles. J Dairy Sci 88:3070-3078

Molina ACT, Alli I, Konishi Y, Kermasha S (2007) Effect of dephosphorylation on bovine casein. Food Chem 101:1263-1271

Moon JH, Hong YH, Huppertz T, Fox PF, Kelly AL (2009) Properties of casein micelles cross-linked by transglutaminase. Int J Dairy Technol 62:27-32

Morr CV (1967a) Some effects of pyrophosphate and citrate ions upon the colloidal caseinate-phosphate micelles and ultrafiltrate of raw and heated skimmilk. J Dairy Sci 50:1038-1044

Morr C (1967b) Effect of oxalate and urea upon ultracentrifugation properties of raw and heated skimmilk casein micelles. J Dairy Sci 50:1744-1751

Motoki M, Nio N, Takinami K (1984) Functional properties of food proteins polymerized by transglutaminase. Agric Biol Chem 48:1257-1261

Motoki M, Seguro K, Nio N, Takinami K (1986) Glutamine-specific deamidation of $\alpha \mathrm{s}_{1}$-casein by transglutaminase. Agric Biol Chem 50:3025-3030

Mounsey JS, O'Kennedy BT, Kelly PM (2005) Influence of transglutaminase treatment on properties of micellar casein and products made thereof. Lait 85:1-14

Nieuwenhuijse JA, Timmermans W, Walstra P (1988) Calcium and phosphate partitions during the manufacture of sterilized concentrated milk and their relations to the heat stability. Neth Milk Dairy J 42:387-421 
Nio N, Motoki M, Takinami K (1986) Gelation mechanism of protein solution by transglutaminase. Agric Biol Chem 50:851-855

Nipun Babu V, Kannan S (2012) Enhanced delivery of baicalein using cinnamaldehyde cross-linked chitosan nanoparticle inducing apoptosis. Int J Biol Macromol 51:1103-1108

Nogueira Silva N, Bahri A, Guyomarc'h F, Beaucher E, Gaucheron F (2015) AFM study of casein micelles cross-linked by genipin: effects of acid $\mathrm{pH}$ and citrate. Dairy Sci Technol 95:75-86

Nonaka M, Matsuura Y, Nakano K, Motoki M (1997) Improvement of the pH-solubility profile of sodium caseinate by using $\mathrm{Ca}^{2+}$-independent microbial transglutaminase with gelatin. Food Hydrocoll 11:347349

O'Connell JE, Fox PF (2001) Significance and applications of phenolic compounds in the production and quality of milk and dairy products: a review. Int Dairy J 11:103-120

O'Regan J, Mulvihill DM (2009) Preparation, characterisation and selected functional properties of sodium caseinate-maltodextrin conjugates. Food Chem 115:1257-1267

O’Sullivan MM, Kelly AL, Fox PF (2002) Influence of transglutaminase treatment on some physico-chemical properties of milk. J Dairy Res 69:433-442

Odagiri S, Nickerson TA (1965a) Micellar changes in skim milk treated with alkali or acid. J Dairy Sci 48: $1157-1160$

Odagiri S, Nickerson TA (1965b) Complexing of calcium by hexametaphosphate, oxalate, citrate, and ethylenediamine-tetraacetate in milk. II. Dialysis of milk containing complexing agents. J Dairy Sci 48: $19-22$

Oldfield DJ, Singh H, Taylor MW, Pearce KN (2000) Heat-induced interactions of $\beta$-lactoglobulin and $\alpha$ lactalbumin with the casein micelle in pH-adjusted skim milk. Int Dairy J 10:509-518

Oliver CM, Melton LD, Stanley RA (2006) Glycation of caseinate by fructose and fructooligosaccharides during controlled heat treatment in the 'dry' state. J Sci Food Agric 86:722-731

Omoarukhe ED, On-Nom N, Grandison AS, Lewis MJ (2010) Effects of different calcium salts on properties of milk related to heat stability. Int J Dairy Technol 63:504-511

Ono T, Obata T (1989) A model for the assembly of bovine casein micelles from F2 and F3 subunits. J Dairy Res 56:453-461

Orlien V, Knudsen JC, Colon M, Skibsted LH (2006) Dynamics of casein micelles in skim milk during and after high pressure treatment. Food Chem 98:513-521

Ouanezar M, Guyomarc'h F, Bouchoux A (2012) AFM Imaging of milk casein micelles: evidence for structural rearrangement upon acidification. Langmuir 28:4915-4919

Ozcan-Yilsay T, Lee WJ, Horne D, Lucey JA (2006) Effect of trisodium citrate on rheological properties and microstructure of yogurt. J Dairy Sci 90:1644-1652

Ozer B, Avni Kirmaci H, Oztekin S, Hayaloglu A, Atamer M (2007) Incorporation of microbial transglutaminase into non-fat yogurt production. Int Dairy J 17:199-207

Panyam D, Kilara A (1996) Enhancing the functionality of food proteins by enzymatic modification. Trends Food Sci Technol 7:120-125

Pearse MJ, Linklater PM, Hall RJ, Mackinlay AG (1986) Effect of casein micelle composition and casein dephosphorylation on coagulation and syneresis. J Dairy Res 53:381-390

Pepper L, Thompson MP (1963) Dephosphorylation of $\alpha_{\mathrm{S}^{-}}$and $\mathrm{K}$-caseins and its effect on micelle stability in the $\kappa-\alpha_{\mathrm{S}}$-casein system. J Dairy Sci 46:764-767

Philippe M, Gaucheron F, Le Graët Y, Garem A, Michel F (2003) Physicochemical characterization of calcium-supplemented skim milk. Lait 83:45-59

Philippe M, Gaucheron F, Le Graët Y (2004) Physicochemical characteristics of calcium supplemented skim milk: comparison of three soluble calcium salts. Milchwissenchaft 59:498-504

Philippe M, Le Graët Y, Gaucheron F (2005) The effect of different cations on the physicochemical characteristics of casein micelles. Food Chem 90:673-683

Pierre A, Brulé G (1981) Mineral and protein equilibria between the colloidal and soluble phases of milk at low temperature. J Dairy Res 48:417-428

Pierre A, Fauquant J, Le Graët Y, Piot M, Maubois JL (1992) Préparation de phosphocaséinate natif par microfiltration sur membrane. Lait 72:461-474

Pitkowski A, Nicolai T, Durand D (2008) Scattering and turbidity study of the dissociation of casein by calcium chelation. Biomacromolecules 9:369-375

Pouliot M, Pouliot Y, Britten M, Maubois JL, Fauquant J (1994) Study of the dissociation of $\beta$-casein from native phosphocaseinate. Lait 74:325-332

Qi PX (2007) Studies of casein micelle structure: the past and the present. Lait 87:363-383

Raikos V (2010) Effect of heat treatment on milk protein functionality at emulsion interfaces. A review. Food Hydrocoll 24:259-265

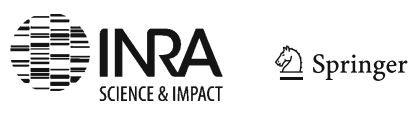


Raouche S, Naille S, Dobenesque M, Bot A, Jumas JC, Cuq JL, Marchesseau S (2009a) Iron fortification of skim milk: minerals and ${ }^{57} \mathrm{Fe}$ Mössbauer study. Int Dairy J 19:53-63

Raouche S, Dobenesque M, Bot A, Cuq JL, Marchesseau S (2009b) Casein micelles as vehicle for iron fortification of foods. Eur Food Res Technol 229:929-935

Regnault S, Dumay E, Cheftel JC (2006) Pressurisation of raw skim milk and of a dispersion of phosphocaseinate at $9{ }^{\circ} \mathrm{C}$ or $20^{\circ} \mathrm{C}$ : effects on the distribution of minerals and proteins between colloidal and soluble phases. J Dairy Res 73:91-100

Reimerdes EH, Roggenbuck G (1980) Chemistry and technology of milk proteins. I. Modification of beta-casein and casein micelles by acid phosphatase from potatoes. Milchwissenschaft 35 : 195-201

Riener J, Noci F, Cronin DA, Morgan DJ, Lyng JG (2009) The effect of thermosonication of milk on selected physicochemical and microstructural properties of yoghurt gels during fermentation. Food Chem 114: 905-911

Rollema HS (2003) Caseinates. In W. Y. Aalbersberg, R. J. Hamer, P. Jasperse, H. H. J. de Jongh, C. G. de Kruif, P. Walstra, and F. A. de Wolf (Eds.), Progress in biotechnology: industrial proteins in perspective, vol. 23 (pp. 255-259, 269). Amsterdam, Elsevier Science Ltd

Rose D, Tessier H (1959) Composition of ultrafiltrates from milk heated at 80 to $230 \mathrm{~F}$ in relation to heat stability. J Dairy Sci 42:969-980

Salaun F, Mietton B, Gaucheron F (2007) Influence of mineral environment on the buffering capacity of casein micelles. Milchwissenchaft 62:20-23

Santos CV, Tomasula PM (2000) Acylation and solubility of casein precipitated by carbon dioxide. J Food Sci 65:227-230

Scaloni A, Perillo V, Franco P, Fedele E, Froio R, Ferrara L, Bergamo P (2002) Characterization of heatinduced lactosylation products in caseins by immunoenzymatic and mass spectrometric methodologies. Biochim Biophys Acta (BBA)-Proteins and Proteomics 1598:30-39

Schey A (2003) Texture improvement of fermented dairy products by enzymatic crosslinking with transglutaminase. In: Fermented milk. Proceedings of the IDF-seminar on Aroma and Texture of Fermented Milk, Kolding, Denmark, pp. 371-375

Schmidt DG (1982) Association of caseins and casein micelle structure. Dev Dairy Chem 1:61-86

Schokker EP, Church JS, Mata JP, Gilbert EP, Puvanenthiran A, Udabage P (2011) Reconstitution properties of micellar casein powder: effects of composition and storage. Int Dairy J 21:877-886

Schrader K, Buchheim W (1998) High pressure effects on the colloidal calcium phosphate and the structural integrity of micellar casein in milk. II. Kinetics of the casein micelle disintegration and protein interactions in milk. Kiel Milchwirtsch Forschungsber 50:79-88

Schuck P, Piot M, Méjean S, Le Graët Y, Fauquant J, Brulé G, Maubois JL (1994) Déshydratation par atomisation de phosphocaséinate natif obtenu par microfiltration sur membrane. Lait 74:375-388

Schuck P, Davenel A, Mariette F, Briard V, Méjean S, Piot M (2002) Rehydration of casein powders: effects of added mineral salts and salt addition methods on water transfer. Int Dairy J 12:51-57

Sharma R, Lorenzen PC, Qvist KB (2001) Influence of transglutaminase treatment of skim milk on the formation of epsilon- (gamma-glutamyl)-lysine and the susceptibility of individual proteins towards crosslinking. Int Dairy J 11:785-793

Shibauchi Y, Yamamoto H, Sagara Y (1992) Conformational change of casein micelles by high pressure treatment. In: High pressure and biotechnology, eds. C. Balny, R. Hayashi, K. Heremans \& P. Masson. John Libbey Eurotext Ltd, Montrouge, France, pp 239-241

Siciliano R, Rega B, Amoresano A, Pucci P (2000) Modern mass spectrometric methodologies in monitoring milk quality. Anal Chem 72:408-415

Siciliano R, Mazzeo M, Arena S, Renzone G, Scaloni A (2013) Mass spectrometry for the analysis of protein lactosylation in milk products. Food Res Int 54:988-1000

Sikand V, Tong PS, Walker J (2013) Effect of adding salt during the diafiltration step of milk protein concentrate powder manufacture on mineral and soluble protein composition. Dairy Sci Technol 93:401-413

Silva CJSM, Sousa F, Gübitz G, Cavaco-Paulo A (2004) Chemical modifications on proteins using glutaraldehyde. Food Technol Biotechnol 42:51-56

Silva NN, Piot M, de Carvalho AF, Violleau F, Fameau AL, Gaucheron F (2013) pH-induced demineralization of casein micelles modifies their physico-chemical and foaming properties. Food Hydrocoll 32:322-330

Silva NN, Saint Jalmes A, De Carvalho A, Gaucheron F (2014) Development of casein microgels from crosslinking of casein micelles by genipin. Langmuir 30:10167-10175

Sitohy M, Chobert JM, Haertle T (1995) Phosphorylation chimique des protéines du lait. Influence des conditions de la reaction. Colloques de l'INRA (France). no. 71 
Slattery H, Fitzgerald RJ (1998) Functional properties and bitterness of sodium caseinate hydrolysates prepared with a Bacillus proteinase. J Food Sci 63:418-422

Smiddy MA, Martin JEGH, Kelly AL, de Kruif CG, Huppertz T (2006) Stability of casein micelles crosslinked by transglutaminase. J Dairy Sci 89:1906-1914

Song F, Zhang LM, Yang C, Yan L (2009) Genipin-crosslinked casein hydrogels for controlled drug delivery. Int J Pharm 373:41-47

Steffan W, Balzer H, Lippert F, Sambor BC, Bradbury AGW, Henle T (2006) Characterization of casein lactosylation by capillary electrophoresis. Eur Food Res Technol 222:467-471

Swaisgood HE (1992) Chemistry of the caseins. In: Fox PF (ed) Advanced dairy chemistry: vol 1, 2nd edn. Elsevier Applied Science, Proteins New York, pp 63-110

Swaisgood HE (2003) Chemistry of caseins. In Fox PF, McSweeney PLH., Eds Advanced dairy chemistryproteins part A, 3rd edn.; Kluwer Academic/Plenum Publishers: New York, Vol. 1, pp 139-201

Tang C, Yang XQ, Chen Z, Wu H, Peng ZY (2005) Physicochemical and structural characteristics of sodium caseinate biopolymers induced by microbial transglutaminase. J Food Biochem 29:402-421

Timmer-Keetels CJ, Nieuwenhuisje JA, Zijtveld-van der Wiel JH (2012). Food products having improved heat stability. U.S. Patent 0231117 A1

Titapiccolo GI, Corredig M, Alexander M (2010) Modification to the renneting functionality of casein micelles caused by nonionic surfactants. J Dairy Sci 93:506-514

Tran Le, Saveyn P, Hoa HD, Van der Meeren P (2008) Determination of heat-induced effects on the particle size distribution of casein micelles by dynamic light scattering and nanoparticle tracking analysis. Int Dairy J 18:1090-1096

Tuinier R, de Kruif CG (2002) Stability of casein micelles in milk. J Chem Phys 117:1290-1295

Udabage P, McKinnon IR, Augustin MA (2000) Mineral and casein equilibria in milk: effects of added salts and calcium-chelating agents. J Dairy Res 67:361-370

Vaia B, Smiddy MA, Kelly AL, Huppertz T (2006) Solvent-mediated disruption of bovine casein micelles at alkaline pH. J Agric Food Chem 54:8288-8293

Van Boekel MAJS (1998) Effect of heating on Maillard reactions in milk. Food Chem 62:403-414

Van Boekel MAJS (1999) Heat-induced deamidation, dephosphorylation and breakdown of caseinate. Int Dairy J 9:237-241

Van Dijk HJM (1991) The properties of casein micelles. 4. The effects of the addition of $\mathrm{NaCl}, \mathrm{MgCl}_{2}$ or $\mathrm{NaOH}$ on the partition of $\mathrm{Ca}, \mathrm{Mg}$ and $\mathrm{PO}_{4}$ in cow's milk. Neth Milk Dairy J 45:241-251

Van Dijk HJM (1992) The properties of casein micelles. VI: behaviour above $\mathrm{pH} 9$, and implications for the micelle model. Nederlands melk en Zuiveltijdschrift 46:101-113

Van Hekken DL, Holsinger VH (2000) Use of cold microfiltration to produce unique $\beta$-casein enriched milk gels. Lait 80:69-76

Van Hekken DL, Strange ED (1994) Rheological properties and microstructure of dephosphorylated whole casein rennet gels. J Dairy Sci 77:907-916

Van Hooydonk ACM, Hagedoorn HG, Boerrigter IJ (1986) pH induced physico-chemical changes of casein micelles in milk and their effect on renneting. 2. Effect of $\mathrm{pH}$ on renneting of milk. Neth Milk Dairy J 40:281-296

Vasbinder AJ, Rollema HS, De Kruif CG (2003) Impaired rennetability of heated milk; study of enzymatic hydrolysis and gelation kinetics. J Dairy Sci 86:1548-1555

Vercet A, Oria R, Marquina P, Crelier S, Lopez-Buesa P (2002) Rheological properties of yoghurt made with milk submitted to manothermosonication. J Agric Food Chem 50:6165-6171

Vidal V, Marchesseau S, Lagaude A, Cuq JL (1998) Influence of chemical agents on casein interactions in dairy products: chemical modification of milk proteins. Colloids and Surface B: Biointerfaces 12:7-14

Vidal V, Marchesseau S, Cuq JL (2002) Physicochemical properties of acylated casein micelles in milk. J Food Sci $67: 42-47$

Visser J, Minihan A, Smits P, Tjan SB, Heertje I (1986) Effects of $\mathrm{pH}$ and temperature on the milk salt system. Neth Milk Dairy J 40:351-368

Walstra P (1990) On the stability of casein micelles. J Dairy Sci 73:1965-1979

Walstra P (1999) Casein sub-micelles: do they exist? Int Dairy J 9:189-192

Walstra P (2002) Physical chemistry of foods. Marcel Dekker Incorporated: New York

Walstra P, Wouters JTM, Geurts T (2006) Dairy science and technology; 2nd ed. Taylor and Francis Group: Boca Raton, Vol. 3, pp 109-157

Wang J, Su Y, Jia F, Jin H (2013) Characterization of casein hydrolysates derived from enzymatic hydrolysis. Chem Central J 7:62,1-8

Ward BR, Goddard SJ, Augustin MA, McKinnon IR (1997) EDTA-induced dissociation of casein micelles and its effect on foaming properties of milk. J Dairy Res 64:495-504 
Yamaguchi S, Yokoe M (2000) A novel protein-deamidating enzyme from Chryseobacterium proteolyticum sp. nov., a newly isolated bacterium from soil. Appl Environ Microbiol 66:3337-3343

Yamaguchi S, Jeenes DJ, Archer DB (2001) Protein-glutaminase from Chryseobacterium proteolyticum, an enzyme that deamidates glutamyl residues in proteins. Eur J Biochem 268:1-13

Yamauchi K, Yoneda Y (1978) Effect of dephosphorylation of casein on its coagulation and proteolysis by chymosin. Agric Biol Chem 42:1031-1035

Yamauchi K, Takemoto S, Tsugo T (1967) Calcium-binding property of dephosphorylated caseins. Agric Biol Chem 31:54-63

Yang M, Shi Y, Wang P, Lui H, Wen P, Ren (2014) Effect of succinylation on the functional properties of yak caseins: a comparison with cow caseins. Dairy Sci Technol 94:359-372

Ye A (2011) Functional properties of milk protein concentrates: emulsifying properties, adsorption and stability of emulsions. Int Dairy J 21:14-20

Yong YH, Yamaguchi S, Gu YS, Mori T, Matsumura Y (2004) Effects of enzymatic deamidation by proteinglutaminase on structure and functional properties of alpha-zein. J Agric Food Chem 52:7094-7100

Yong YH, Yamaguchi S, Matsumura Y (2006) Effects of enzymatic deamidation by protein-glutaminase on structure and functional properties of wheat gluten. J Agric Food Chem 54:6034-6040 